\title{
Biomass fast pyrolysis in a drop tube reactor for bio oil production: Experiments and modeling
}

\author{
Chamseddine Guizani ${ }^{\mathrm{a}, *}$, Sylvie Valin ${ }^{\mathrm{a}}$, Joseph Billaud ${ }^{\mathrm{a}}$, Marine Peyrot ${ }^{\mathrm{a}}$, Sylvain Salvador ${ }^{\mathrm{b}}$ \\ ${ }^{a}$ CEA, LITEN/DTBH/SBRT/LTB, 38054 Grenoble cedex 09, France \\ ${ }^{\mathrm{b}}$ RAPSODEE, Mines Albi, CNRS UMR 5302, Route de Teillet, 81013 ALBI CT Cedex 09, France
}

Keywords:

Biomass

Fast-pyrolysis

Drop tube reactor

Experiments

Modeling

A B S T R A C T

Woody biomass fast pyrolysis in Entrained Flow Reactor (EFR) is studied both with experiments in a lab scale drop tube reactor (DTR) and simulations with a $1 \mathrm{D}$ model. The parameters of the study are tem perature $\left(450600^{\circ} \mathrm{C}\right)$, woody biomass particle size $(370640 \mu \mathrm{m})$ and gas residence time $(12.6$ $20.6 \mathrm{~s}$ ). The most critical phenomena affecting the bio oil yield are considered in the model: heating of the biomass particles, slip velocity of the biomass particles varying with biomass/char properties, bio mass pyrolysis and tar cracking. The analyses of all products char, bio oil and gas also brought infor mation on the advancement of the pyrolysis and cracking for the different tests. The reactor temperature and particle size were found to have a major influence on the pyrolysis product distribution. The produc tion of bio oil reaches a maximum of $62.4 \mathrm{wt} . \%$ at $500{ }^{\circ} \mathrm{C}$ for the $370 \mu \mathrm{m}$ particles. The particle conversion advancement is then estimated at $94 \%$ at the reactor exit. The bio oil yield is lower at higher tempera tures for a constant particle size due to tar cracking. At $550{ }^{\circ} \mathrm{C}$, increasing the particle size from $370 \mu \mathrm{m}$ to $640 \mu \mathrm{m}$ induces a decrease of the bio oil yield from 48.3 to $34.8 \mathrm{wt}$.\%, which was shown to be due to incomplete pyrolysis of the particles, because of a too short residence time as well as a too long heating time of particles. The pyrolysis conditions temperature, particle size were not found to have any significant influence on the bio oil properties, such as acidity.

\section{Introduction}

Actual data as well as serious forecasts on the decreasing avail ability of fossil resources and the increasing pollution in the future, state on the necessity of more sustainable policies in the different fields of energy, agriculture, industry and services [1]. Biomass, if managed in a sustainable way, represents a renewable energy resource. Woody biomass was used since mankind domesticated fire for various applications such as heating and cooking. Nowa

\footnotetext{
* Corresponding author.

E-mail address: guizani.c@gmail.com (C. Guizani).
}

days, these applications remain the major ones for energy recovery from biomass by combustion, especially in the poor countries.

Pyrolysis is another thermochemical way to convert biomass into liquid bio oil, gas and solid char. The biomass pyrolysis reac tion is performed in the absence of oxygen and in a typical temper ature range of $450600^{\circ} \mathrm{C}$. The proportions of gas, solid and liquids highly depend on the pyrolysis process operating conditions [2]. The choice of the technology is conditioned by the nature of the most desired pyrolysis product at the reactor downstream. For instance, fast pyrolysis performed at temperatures of $400600{ }^{\circ} \mathrm{C}$ and at high heating rates, allows maximizing the bio oil yield. Bio oil has nearly the same calorific value as the initial wood; it is more easily transportable and has a higher energy density 


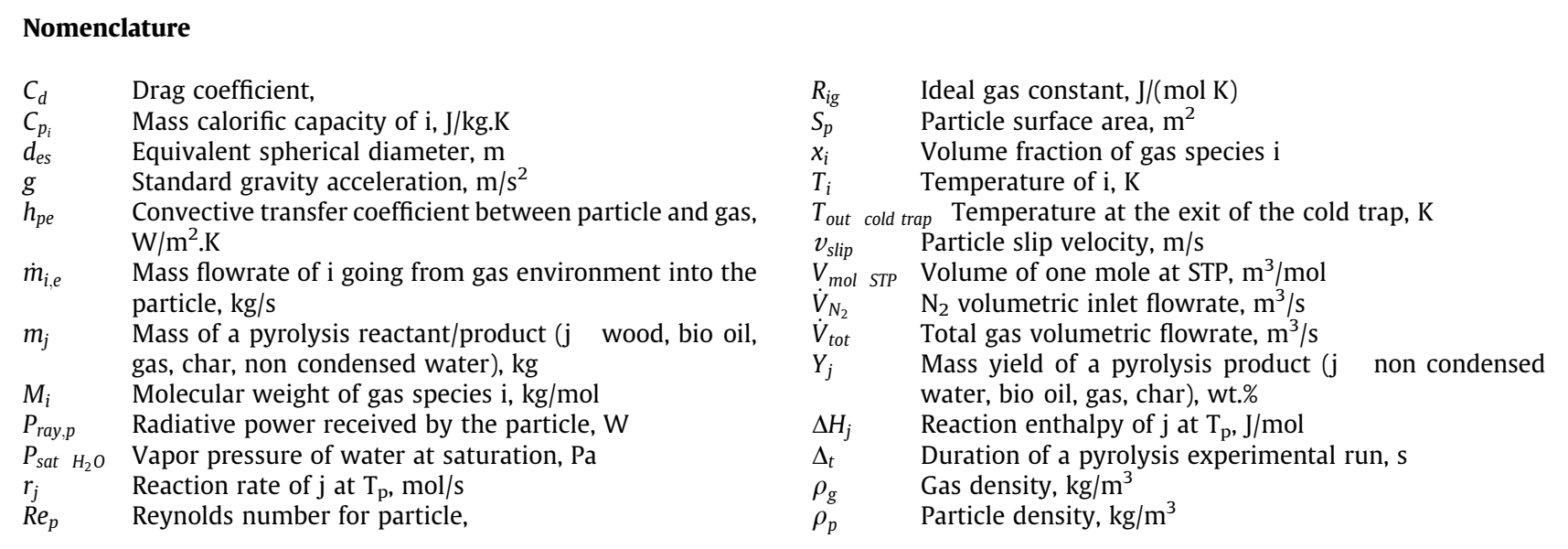

(energy per cubic meter) than the raw biomass. Nevertheless, it presents some drawbacks related to its acidic nature, high oxygen and water contents causing problems for storage and combustion [3].

Biomass fast pyrolysis for bio oil production is most commonly performed in Fluidized Bed Reactors (FBR). These reactors provide a very good heat transfer to the biomass particles by conduction and convection, which allows reaching high heating rates. How ever, some difficulties are induced by the presence of the heat car rier solid (fluidization, separation from the pyrolysis products etc...) [3]. The Entrained Flow Reactor (EFR) could constitute a simpler alternative to FBR. This type of reactor is well known for coal gasification and is then operated at high temperature $\left(1500^{\circ} \mathrm{C}\right.$ ) and high pressure (over 30 bars) to produce a syngas that is rich in $\mathrm{H}_{2}$ and $\mathrm{CO}$. In such a reactor, solid particles, ground to size under millimeter, are fed by the top. They are submitted to a high heat flux, while they drop along the reactor. The solid residence time is typically of a few seconds in the reactor. The principle of EFR (fine biomass particles dropped in a hot reactor) could be used for fast pyrolysis, by adapting the operation conditions and espe cially the gas environment and temperature so as to maximize the bio oil yield.

Some disadvantages of EFR compared to FBR can however be anticipated: lower heat transfer to the biomass particles, need for fine grinding of biomass energy costly step to reach a complete conversion before leaving the reactor.

Despite of these, the EFR technology is still very attractive due to its operation simplicity. The number of studies dealing with bio mass pyrolysis in FBR is huge, while no more than a few tenths of studies deal with biomass flash pyrolysis in EFR conditions for bio oil production. To our knowledge, only two attempts were made to develop fast pyrolysis in an EFR at pilot scale [4]. The biomass feed ing rate was between 50 and $100 \mathrm{~kg} / \mathrm{h}$ and in both cases, the reac tor was heated by combustion gases of a propane burner [4 7]. One main challenge associated with this technology seemed to lie in the control of the biomass particle residence time, which should be long enough to ensure heating of the whole particle up to devolatilisation temperature [4], and short enough to limit tar cracking [5].

All other studies investigating biomass pyrolysis in EFR condi tions were performed in electrically heated drop tube reactors (DTRs) [8 14]. These lab scale reactors well reproduce some important EFR characteristics such as heat flux, residence time and particle size. The reactor dimensions, operating conditions and main results are given in Table 1 . In most of these studies, different parameters were varied (temperature, biomass particle size, biomass feeding rate, inlet gas flowrate) with the objective to determine the optimal values so as to maximize the bio oil yield. The most appropriate temperature for all studies was between 500 and $600{ }^{\circ} \mathrm{C}$, while there was no common optimal particle size from all considered studies. The pyrolysis temperature should come from a compromise between biomass particle extent and sec ondary tar cracking $[8,12,13]$, the latter one also depending on vapor residence time. Increasing the particle size induces limita tions to heat transfer inside the solid, as well as a shorter solid res idence time in the reactor, which may cause incomplete pyrolysis [8]. The solid initial density also has a direct influence on particle residence time [13].

Even if all together, these studies allow identifying the most important phenomena and issues associated with bio oil produc tion from biomass particles in EFR conditions, none of them has been coupled to a modeling approach which could give a more pre cise comprehension of the conversion process and help evaluating the respective contributions of the different parameters on the overall result.

On the other hand, a few models have been developed to simulate biomass gasification in EFR. However, most of them mainly focus on the chemistry of pyrolysis [15] without consider ing the influence of particle size on heat transfer limitation or residence time. This aspect was considered in other models $[16,17]$ validated for higher temperatures representative of gasifi cation process rather than fast pyrolysis to bio oil one. Gorton et al. [6] developed an interesting model of biomass fast pyrolysis, in parallel with their experiments in the above mentioned pilot scale EFR [5,7]. This model provided insight into the phenomena, as well as equations which can be used in the design of industrial reactors, such as simple kinetic laws for biomass pyrolysis and tar cracking.

In the present work, our aim is to improve comprehension of entrained flow fast pyrolysis of biomass using both experimental and modeling approaches. The experiments are performed in a lab scale drop tube reactor, in conditions representative of EFR operation. The parameters of the study are temperature, woody biomass particle size and gas residence time. For each experimen tal condition, the solid, gaseous and liquid yields are measured, and characterization of all types of products gas, bio oil, solid residue

are performed. The objective is to have a good insight into the influence of tested parameters on all yields and properties, and also to bring basis data to a model developed in parallel to the experi ments. The model aims at giving a better comprehension of the 
Table 1

Reactor dimensions, operating conditions and main results of literature DTR studies.

\begin{tabular}{|c|c|c|c|c|c|c|}
\hline Reference & Biomass & $\begin{array}{l}\text { Reactor length/diameter } \\
(\mathrm{m})\end{array}$ & $\begin{array}{l}\text { Biomass feeding rate } \\
(\mathrm{kg} / \mathrm{h})\end{array}$ & $\begin{array}{l}\text { Biomass particle size } \\
(\mu \mathrm{m})\end{array}$ & $\begin{array}{l}\text { Temperature } \\
\left({ }^{\circ} \mathrm{C}\right)\end{array}$ & $\begin{array}{l}\text { Maximum bio-oil yield } \\
\text { (wt\%) }\end{array}$ \\
\hline [8] & Oak & $1.8 / 0.021$ & 2.0 & $200-600$ & $450-650$ & 70 \\
\hline [11] & $\begin{array}{l}\text { Apricot stone, legume } \\
\text { straw }\end{array}$ & $1.8 / 0.02$ & Not specified & $200-2000$ & $500-800$ & 66 \\
\hline [12] & Rapeseed & $0.7 / 0.012$ & 0.12 & $224-1800$ & $400-700$ & 75 \\
\hline [13] & $\begin{array}{l}\text { Sugarcane and cassava } \\
\text { residues }\end{array}$ & $1.0 / 0.0077$ & 0.1 & $250-450$ & 450 & 70 \\
\hline [14] & Eucalyptus bark & $1.2 / 0.0103$ & $0.08 / 0.15$ & $212-500$ & $400-550$ & 65 \\
\hline [9] & Red oak & $3.05 / 0.035$ & 1.0 & $250-850$ & $400-800$ & 60 \\
\hline [10] & Wood fibers & $4.2 / 0.05$ & 1.0 & $150-1000$ & $400-550$ & 58 \\
\hline
\end{tabular}

conversion process, and to provide a representation which will be used in further design of pilot or industrial scale EFR.

\section{Material and methods}

\subsection{The raw biomass}

Raw biomass used in this work is beech wood supplied by the SPPS company (France). Wood moisture was determined by drying at $105^{\circ} \mathrm{C}$ according to the NF EN 14774 standard. Ash content was determined by burning the sample in air at $550{ }^{\circ} \mathrm{C}$ according to the NF EN 14775 standard. Ultimate analysis of the wood sample was performed by the SOCOR laboratory (France). The oxygen content was determined by difference to the sum of $\mathrm{C}, \mathrm{H}, \mathrm{N}$ and ashes. The analyses are provided in Table 2 .

Three classes of particle size were selected by sieving: $315450 \mu \mathrm{m}$ (class 1); $450630 \mu \mathrm{m}$ (class 2); $630800 \mu \mathrm{m}$ (class 3 ). Particle size distribution for each class was determined using a particle size analyzer (CAMSIZER) (minimal largest chord diame ter, which is close to the width of the particle, discriminated by sieving). The particle size distributions were near Gaussian ones. The mean particle sizes of the three classes were respectively $370 \mu \mathrm{m}, 490 \mu \mathrm{m}$ and $640 \mu \mathrm{m}$. These mean values are used along this paper to name the three particle classes. They are also used as the mean particle sizes in the model.

\subsection{Experimental device}

The experimental device is a Drop Tube Reactor (DTR) located at the School of Mines in Albi, France. A schematic representation of the biomass pyrolysis experimental set up is shown in Fig. 1. The device was previously used in several studies focusing on the pyrolysis and gasification of biomass at temperatures beyond $800{ }^{\circ} \mathrm{C}[18,19]$. The experimental device consists of three main parts: a biomass feeding system, a reactor, and a collection system

Table 2

Proximate and ultimate analyses of the beech wood.

\begin{tabular}{ll}
\hline Proximate analysis & \\
Moisture [wt.\% ar"] & 8.7 \\
Volatile Matter [wt.\% db" $\left.{ }^{* *}\right]$ & 84.3 \\
Fixed carbon [wt.\% db] & 15.2 \\
Ash $\left(815^{\circ} \mathrm{C}\right)[\mathrm{wt} . \% \mathrm{db}]$ & 0.5 \\
Ultimate analysis [wt.\% db] & \\
$\mathrm{C}$ & 49.1 \\
$\mathrm{H}$ & 5.7 \\
$\mathrm{~N}$ & 0.15 \\
$\mathrm{~S}$ & 0.045 \\
$\mathrm{O}$ (by difference) & 44.5 \\
\hline$*$ ar: as received. & \\
$*$ db: dry basis. &
\end{tabular}

for the reaction products. A gas analyzer is located after the collec tion system.

\subsubsection{The biomass feeding system}

The device comprises a homemade weight metering device, allowing a continuous and constant injection of biomass over time. It consists of a hopper and a treadmill belt mounted on a precision electronic scale. The mass change with time is used to control the treadmill speed and thus the biomass feeding rate. A vibrating chute homogenizes the particle flow before injecting them into the reactor using pneumatic transport. The injection probe at the top of the reactor is water cooled $\left(30^{\circ} \mathrm{C}\right)$ to prevent the biomass from pyrolysing before entering the reactor hot zone. A dispersion dome located a few millimeters under the exit of the injection probe allows spreading the particles homogeneously over the reac tor section. A small flowrate of $\mathrm{N}_{2}$ is fed with biomass as transport gas. The main $\mathrm{N}_{2}$ stream passes through an electric preheater, which allows raising its temperature to the reactor one, with the aim to ensure the most homogeneous temperature as possible in the reactor.

\subsubsection{The reactor}

The reactor is composed of a total $2.3 \mathrm{~m}$ long, $0.075 \mathrm{~m}$ in inter nal diameter alumina tube. The heated zone of $1.2 \mathrm{~m}$ long is heated by 3 independent electric resistors. The reactor is thermally insulated.

\subsubsection{The collection system for the reaction products}

A new collection system was developed and used in this study, in order to recover all of the gas, liquid and solid products, and thus to analyze them. A schematic representation of the whole biomass pyrolysis experimental set up is shown in Fig. 1.

The collection device consists of a heated sampling probe with a double jacket (1). Argon is injected in the lower part of the probe, in the double jacket annular space, and exits at the top of the probe through 3 thin peripheral slits of $1 \mathrm{~mm}$ height and $64 \mathrm{~mm}$ in length (the circumference is $220 \mathrm{~mm}$ ). Argon exiting from the peripheral slits forms a "barrier" preventing the introduction of air inside the probe and ensuring the pyrolysis products to be collected in the probe. The suction of the pyrolysis products inside the collec tion probe is mainly ensured by a principal pump (7). The second pump (8) is used to derive a small fraction of gas stream to gas ana lyzer (micro gas chromatograph, $\mu \mathrm{GC}$ ). The suction flow rate is controlled via 2 mass flowmeters controllers. In each pyrolysis experimental run, it is checked to be slightly higher than the sum of the $\mathrm{N}_{2}$ flowrate in the furnace and of the pyrolysis gas flow rate (estimated at around $1 \mathrm{~L} / \mathrm{min}$ for a biomass mass flow rate of $1 \mathrm{~g} / \mathrm{min}$ ) in order to suck only a part of the $A r$ and no air from the outside. This is checked via the $\mu \mathrm{GC}$ analysis before starting the experiment: gas stream $\mathrm{O}_{2}$ free and containing $\mathrm{Ar}$. 


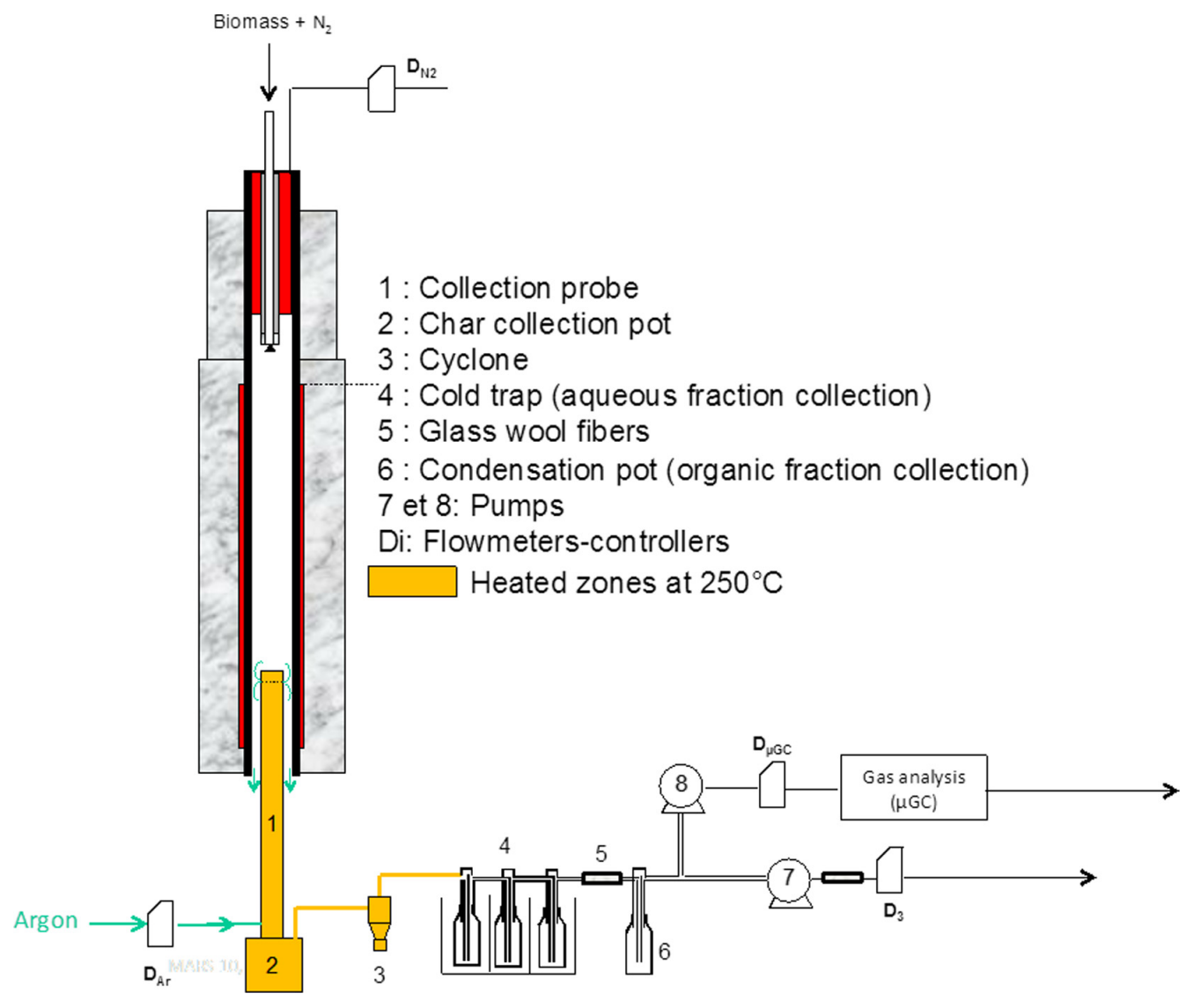

Fig. 1. Schematic representation of the biomass pyrolysis experimental set-up.

The char particles are collected at the bottom of the collection probe in a char collection pot. A very small fraction of fines is car ried out from the collection pot and is recovered in the cyclone. At the exit of the cyclone, the gas flow is divided into three parallel flows so as to ensure a better subsequent cooling in the condensa tion pots.

All parts of the pyrolysis products collection device, going from the top of the collection probe to the cold trap, are electrically heated at $250{ }^{\circ} \mathrm{C}$ to prevent condensation of the bio oil.

The three parallel gas flows enter a cold trap (4) consisting of a rectangular tank containing 6 pots with dip tubes $(0.5 \mathrm{~L}$, Schott). The 6 pots are arranged in pairs of 3 parallel lines. To insure the cooling of the condensation pots, the tank is either filled with dry ice (solid $\left.\mathrm{CO}_{2}\right)+$ isopropanol or with ice cubes and water. The presence of the liquid (isopropanol or water) insures a better heat transfer to the pot and a better homoge nization of the temperature in the tank. The temperature at the cold trap exit was measured with a $\mathrm{K}$ type thermocouple. It varied between $10^{\circ} \mathrm{C}$ when dry ice was used, and $15^{\circ} \mathrm{C}$ when standard ice was used.

At the cold trap level, we noticed the formation of aerosols, which were entrained to a final condensation pot, at room temper ature (5 6). The entrance of the condensation pot is lined with glass wool fibers. When the aerosols percolate through the glass wool fibers (5), they condensate and start flowing along the con densation pot dip tube (6). This staged condensation allowed us obtaining two bio oil fractions. The first one, recovered in the cold trap, is an aqueous fraction (AF) with a high water content. The second one, recovered in the glass wool fibers lined pot, is an organic fraction (OF) and contains much less water and mostly organic molecules. In the following of the manuscript, the term "bio oil" will be used to represent the sum of AF and OF.

\subsection{Experimental conditions}

Experimental campaigns have been undertaken to study the influence of the process parameters reactor temperature, bio mass particle size and gas residence time on the pyrolysis prod ucts distribution. The different parameters were set to the following values:

- Temperature: $450^{\circ} \mathrm{C}, 500{ }^{\circ} \mathrm{C}, 550^{\circ} \mathrm{C}$ and $600{ }^{\circ} \mathrm{C}$,

- Particle size: $370 \mu \mathrm{m}, 490 \mu \mathrm{m}$ and $640 \mu \mathrm{m}$,

- Gas residence time: 12.6 s, $16.6 \mathrm{~s}$ and $20.6 \mathrm{~s}$, which was set by varying the $\mathrm{N}_{2}$ flowrate.

The types of products recovered and analyzed in this study are: gas comprising the gas species quantified by $\mu \mathrm{GC}$, char, and bio oil comprising the aqueous and organic fraction mentioned above.

A summary of the pyrolysis experimental runs is given in Table 3. No replicate experiment was performed.

\subsection{Mass and chemical energy balances}

The overall mass balance of the process is obtained from the mass of the injected wood particles on the one hand, and the mass of the collected char (in char collection pot and cyclone), of bio oil, of pyrolysis gas, and of water remaining as steam on the other hand. 
Table 3

Summary of the pyrolysis experimental runs.

\begin{tabular}{|c|c|c|c|c|}
\hline \multirow[b]{2}{*}{ Pyrolysis runs } & & \multicolumn{3}{|c|}{ Experimental conditions } \\
\hline & & Temperature $\left[{ }^{\circ} \mathrm{C}\right]$ & Particle size $[\mu \mathrm{m}]$ & Gas residence time [s] \\
\hline \multirow[t]{4}{*}{ Effect of the reactor temperature $(\mathrm{T})$} & Run- $450^{\circ} \mathrm{C}$ & 450 & 370 & 16.6 \\
\hline & Run- $500^{\circ} \mathrm{C}$ & 500 & 370 & 16.6 \\
\hline & Run- $550^{\circ} \mathrm{C}$ & 550 & 370 & 16.6 \\
\hline & Run- $600^{\circ} \mathrm{C}$ & 600 & 370 & 16.6 \\
\hline \multirow[t]{3}{*}{ Effect of particle size (PS) } & Run-370 $\mu \mathrm{m}$ & 550 & 370 & 16.6 \\
\hline & Run- $490 \mu \mathrm{m}$ & 550 & 490 & 16.6 \\
\hline & Run-640 $\mu \mathrm{m}$ & 550 & 640 & 16.6 \\
\hline \multirow[t]{3}{*}{ Effect of the gas residence time (GRT) } & Run-12.6 s & 550 & 370 & 12.6 \\
\hline & Run-16.6 s & 550 & 370 & 16.6 \\
\hline & Run-20.6 s & 550 & 370 & 20.6 \\
\hline
\end{tabular}

The total mass of pyrolysis gas is calculated from $\mu \mathrm{GC}$ measure ments species listed in Section 2.5.1. using $\mathrm{N}_{2}$ as tracer gas species.

$$
\begin{array}{ll}
V_{\text {tot }} & \frac{V_{\mathrm{N}_{2}}}{x_{N_{2}}} \\
m_{\text {gas }} & \sum_{\text {p pyro gas }} x_{i} \frac{V_{\text {tot }}}{V_{\text {mol STP }}} M_{i} \Delta t
\end{array}
$$

The temperature at the exit of the cold trap varied between 10 and $15{ }^{\circ} \mathrm{C}$. In this temperature range, the amount of water in the vapor state cannot be neglected. As it could not be measured directly, it was estimated according to the Rankin formula [20]:

$P_{\text {sat } \mathrm{H}_{2} \mathrm{O}} \quad 1.02310^{5} \mathrm{e}^{\left(13.7 \frac{5120}{\mathrm{~T}_{\text {out }} \text { cold trap }}\right)}$

The water saturation pressure is slightly underestimated according to this formula because the device is in a slight depres sion state. Nevertheless this remains a good approximation. There after, it was possible to determine the mass of water in the gas state:

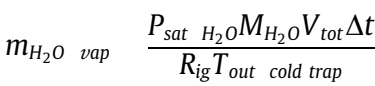

The yield of a pyrolysis product $j$ is calculated as follows:

$Y_{j} \quad \frac{m_{j}}{m_{\text {wood }}} 100$

The uncertainty associated with each product yield is estimated at $10 \%$.

After measuring or calculating the product Higher Heating Values (HHV), a chemical energy balance was set:

Chemical energy balance $\sum_{j} \frac{Y_{j} H H V_{j}}{H H V_{\text {wood }}}$

\subsection{Pyrolysis products characterization}

\subsubsection{Gas analysis}

Gas composition was analyzed using a $\mu \mathrm{GC}$ (Agilent 3000A micro GC) equipped with four columns (two 5 Å molecular sieves, with argon and helium as carrier gas respectively, one Poraplot $U$ column and one Stabilwax column, both with helium as carrier gas). Each column is coupled with a Thermal Conductivity Detector (TCD). The analyzed, calibrated and quantified gas species are: $\mathrm{N}_{2}$, Ar, $\mathrm{O}_{2}, \mathrm{CO}, \mathrm{CO}_{2}, \mathrm{CH}_{4}, \mathrm{C}_{2} \mathrm{H}_{4}, \mathrm{C}_{2} \mathrm{H}_{2}, \mathrm{C}_{2} \mathrm{H}_{6}, \mathrm{C}_{3} \mathrm{H}_{8}, \mathrm{C}_{6} \mathrm{H}_{6}, \mathrm{C}_{7} \mathrm{H}_{8}$ and $\mathrm{H}_{2}$.

\subsubsection{Char characterization}

The $C$ and $H$ contents of chars were determined by ultimate analysis. The HHVs of chars were determined with a bomb calorimeter (Parr 6200).

As some of the pyrolysis conditions did not allow a complete conversion of the wood, the residual fresh/non completely pyrol ysed wood fraction in the char was determined by thermal analy sis. 5 to $10 \mathrm{mg}$ of char were heated in a thermobalance at $5{ }^{\circ} \mathrm{C} / \mathrm{min}$ in $\mathrm{N}_{2}$, up to the temperature at which they were produced in the DTR, and with a holding time of one hour. The weight loss was then determined and the pyrolysis extent at the DTR exit was calculated:

$X \frac{1}{1 \quad Y_{f T R}}$

Where $Y_{D T R}$ is the residual solid yield after the pyrolysis reaction in the DTR, and $Y_{f}$ is the lowest theoretical residual solid yield that can be obtained if the biomass is totally converted in the DTR. It is assumed that TG experiments lead to complete pyrolysis and that the char yield is then similar to what would have been obtained after complete pyrolysis in the DTR. Thus $Y_{f}$ reads:

$Y_{f} \quad Y_{D T R}\left(1 \quad \% w_{\text {loss }}\right.$ TG $)$

With $\% w_{\text {loss }} T G$ is the percentage of weight loss during the TG experiments.

\subsubsection{Bio oil characterization}

Various physical and chemical properties of bio oils were assessed: elemental composition, HHV, water content, density, acidity and chemical composition.

The bio oil HHVs were determined by combustion in the bomb calorimeter. Problems of ignition were encountered with aqueous fraction due to its higher water content. Thus, each sample of aque ous fraction was blended with vegetable oil (with a known HHV of $39.7 \mathrm{MJ} / \mathrm{kg}$ ) at a precisely known mass fraction (varying between 18 and 22 wt.\%). The HHV of the oil + aqueous phase blend was measured in the bomb calorimeter, from which the HHV of the aqueous phase was simply calculated.

The water content of the bio oil organic and aqueous fractions was measured by Karl Fisher titration.

Filling a $1 \mathrm{ml}$ calibrated container with the bio oil and weighing it allowed us calculating the bio oil density.

The acidity of the bio oils was determined by measuring the Total Acid Number (TAN). A KOH solution was used in the presence of phenolphthalein for the acid titration in the oils. This allowed determining the volume of $\mathrm{KOH}$ at the equivalence point. The TAN is expressed in $\mathrm{mg} \mathrm{KOH} / \mathrm{g}$ bio oil.

The chemical composition of bio oils was also studied by means of a GC FID analyzer after diluting the bio oil samples in acetone at a concentration of about 5 wt.\% [21]. An Elite 1701 column (Perkin 
Elmer) was used. Helium was used as a vector gas. The column temperature was initially set at $45^{\circ} \mathrm{C}$ during $10 \mathrm{~min}$, then raised to $230^{\circ} \mathrm{C}$ with a rate of $6{ }^{\circ} \mathrm{C} / \mathrm{min}$ and maintained at this tempera ture for $25 \mathrm{~min}$. Ten chemical compounds glycoaldehyde, acetic acid, hydroxyacetone, formaldehyde, propanoic acid, phenol, 2 methoxyphenol, isoeugenol, levoglucosan and eugenol were quantified in the bio oil. The external calibration was performed using pure compounds (INTERCHEM). These compounds were selected because they were found to be the major ones in previous GC MS analysis with peak identification.

\subsection{Modeling the biomass fast pyrolysis in the DTR: GASPAR model}

GASPAR is a $1 \mathrm{D}$ model developed in FORTRAN language, describing the pyrolysis and gasification of solid particles inside an EFR or DTR. It takes into account particle heating, particle dry ing, pyrolysis reaction, gas phase reactions, and char gasification. Gas and tar reaction in the gas phase are modeled using the CHEM KIN tool. The differential system is solved with LSODE solver, which is appropriate for stiff systems. The modeling tool was val idated against different experiments, presented in [24 26].

The major hypotheses of GASPAR are:

- The drop tube reactor is modeled as a plug flow reactor

- The particles are supposed to be spherical

- Temperature and concentrations are supposed to be uniform inside the particles

- The slip velocity between particles and gas is taken into account. The slip velocity is calculated as follows:

$\frac{d v_{\text {slip }}}{d t} \quad \frac{\left(\rho_{p} \quad \rho_{g}\right)}{\rho_{p}} g \quad \frac{3}{4} C_{d} \frac{\rho_{g}}{\rho_{p}} \frac{1}{d_{e s}} v_{\text {slip }}^{2}$

This slip velocity model has been previously validated with par ticle velocity measurements [22]. Taking it into account is crucial for the correct representation of the particle residence time inside the reactor. The drag coefficient correlation has been adapted by Chen [22] from [23]:

$C_{d} \quad 1.5\left[\frac{24}{\operatorname{Re}_{p}}\left(1+0.173 \operatorname{Re}_{p}^{0.657}\right)+\frac{0.413}{1+16300 \operatorname{Re}_{p}{ }^{1.09}}\right]$

The model takes into account the modifications of the particle characteristics as the pyrolysis reaction proceeds. The particle bulk density $\rho_{p}$ thus continuously varies between that of wood $(661 \mathrm{~kg} /$ $\mathrm{m}^{3}$ ) and that of char $\left(158 \mathrm{~kg} / \mathrm{m}^{3}\right)$, while the particle equivalent spherical diameter $d_{e s}$ is decreased by a shrinking factor of 0.7 .

The heat transfer between gas and solid is modeled through energy balance equations. The energy balance for a solid particle reads, with subscripts $\mathrm{p}$ and e standing for particle and gas envi ronment respectively [24]:

$$
\begin{aligned}
m_{p} C_{p_{p}} \frac{\partial T_{p}}{\partial t} & \sum_{i \text { gas }} m_{i, e} C_{p_{i}}\left(T_{e} \quad T_{p}\right)+h_{p e} S_{p}\left(T_{e} \quad T_{p}\right)+P_{\text {ray }, p} \\
& +\sum_{j}\left(\Delta H_{j} r_{j}\right)
\end{aligned}
$$

GASPAR has been previously developed to describe the pyroly sis and gasification of biomass particles over a wide temperature range $\left(800^{\circ} \mathrm{C} 1400^{\circ} \mathrm{C}\right)$ and gas atmosphere compositions $[25,26]$. For the present work, GASPAR was adapted to model bio mass fast pyrolysis in the $400600{ }^{\circ} \mathrm{C}$ range. Biomass pyrolysis was considered to occur following a one step reaction through which the solid biomass is decomposed into gas, char and tar. The char was assumed to be pure carbon and the tar was represented by the mean molecular $\mathrm{C}_{8} \mathrm{H}_{10} \mathrm{O}_{4}$ formula. Tar is cracked into additional gas if the temperature is high enough as detailed further.

The pyrolysis reaction for the dry ash free biomass $\mathrm{C}_{6} \mathrm{H}_{8.24} \mathrm{O}_{4.09}$ is represented by:

$$
\begin{aligned}
\mathrm{C}_{6} \mathrm{H}_{8.24} \mathrm{O}_{4.09} \rightarrow & \alpha_{1} \mathrm{H}_{2}+\alpha_{2} \mathrm{CO}+\alpha_{3} \mathrm{CO}_{2}+\alpha_{4} \mathrm{CH}_{4}+\alpha_{5} \mathrm{C}_{2} \mathrm{H}_{2}+\alpha_{6} \mathrm{C}_{2} \mathrm{H}_{4} \\
& +\alpha_{7} \mathrm{C}_{2} \mathrm{H}_{6}+\alpha_{8} \mathrm{C}_{3} \mathrm{H}_{8}+\alpha_{9} \mathrm{C}_{6} \mathrm{H}_{6}+\beta_{1} \mathrm{H}_{2} \mathrm{O}+\beta_{2} \mathrm{C}_{7} \mathrm{H}_{8} \\
& +\beta_{3} \mathrm{C}_{8} \mathrm{H}_{10}+\gamma \mathrm{C}+\tau_{1} \mathrm{C}_{8} \mathrm{H}_{10} \mathrm{O}_{4}
\end{aligned}
$$

The stoichiometry of the pyrolysis reaction (Table 4) was fixed according to the experimental results:

- The gas species stoichiometry was fixed leaning on the experi mental gas yields at $500{ }^{\circ} \mathrm{C}$. At this temperature, it was assumed that the gas production was mainly due to the biomass pyroly sis reaction, and that the contribution of tar cracking was negligible.

- The char stoichiometric coefficient was fixed according to the char yield obtained at $600{ }^{\circ} \mathrm{C}$ as we noticed a further char yield decrease between $500{ }^{\circ} \mathrm{C}$ and $600^{\circ} \mathrm{C}$. It is assumed that the bio mass pyrolysis was achieved at this temperature.

- The differences in major gas species and tar yields measured at $600{ }^{\circ} \mathrm{C}$ and at $500{ }^{\circ} \mathrm{C}$ were calculated. The $\mathrm{C}_{8} \mathrm{H}_{10} \mathrm{O}_{4}$ stoichiomet ric coefficient was calculated by difference so that the reaction stoichiometry was balanced. These two test results were, first of all, used to fit the tar cracking reaction stoichiometric coeffi cients. All the gas species yields were higher at $600{ }^{\circ} \mathrm{C}$ than at $500{ }^{\circ} \mathrm{C}$. The differences were ascribed to tar cracking. The stoi chiometric coefficients of the reaction were determined on the basis of these differences. One drawback of this approach is that the tar yield can be overestimated, as the experimental mass balances do not systematically reach $100 \%$ due to experimental errors.

The tar cracking reaction was modeled according to the follow ing reaction:

$$
\begin{aligned}
\mathrm{C}_{8} \mathrm{H}_{10} \mathrm{O}_{4} \rightarrow & \omega_{1} \mathrm{H}_{2}+\omega_{2} \mathrm{CO}+\omega_{3} \mathrm{CO}_{2}+\omega_{4} \mathrm{CH}_{4}+\omega_{5} \mathrm{C}_{2} \mathrm{H}_{4}+\omega_{6} \mathrm{C}_{2} \mathrm{H}_{6} \\
& +\omega_{7} \mathrm{C}_{6} \mathrm{H}_{6}+\omega_{8} \mathrm{C}_{2} \mathrm{H}_{2}
\end{aligned}
$$

The reaction stoichiometry (Table 5) was obtained from the increase in the principal gas species amounts between experi ments at $500{ }^{\circ} \mathrm{C}$ and $600{ }^{\circ} \mathrm{C}$.

In the present modeling approach, the accent is put on the par ticle hydrodynamics inside the reactor, on its residence time and conversion level. The pyrolysis and tar cracking reactions are

Table 4

Mass stoichiometric coefficients of the pyrolysis reaction in GASPAR.

\begin{tabular}{llll}
\hline Formula & Name & Coefficient & Value \\
\hline $\mathrm{H}_{2}$ & Hydrogen & $\alpha_{1}$ & 0.0004 \\
$\mathrm{CO}$ & Carbon monoxide & $\alpha_{2}$ & 0.0909 \\
$\mathrm{CO}_{2}$ & Carbon dioxide & $\alpha_{3}$ & 0.0534 \\
$\mathrm{H}_{2} \mathrm{O}$ & Steam & $\beta_{1}$ & 0.1492 \\
$\mathrm{CH}_{4}$ & Methane & $\alpha_{4}$ & 0.0092 \\
$\mathrm{C}_{2} \mathrm{H}_{2}$ & Acetylene & $\alpha_{5}$ & 0.0003 \\
$\mathrm{C}_{2} \mathrm{H}_{4}$ & Ethylene & $\alpha_{6}$ & 0.0470 \\
$\mathrm{C}_{2} \mathrm{H}_{6}$ & Ethane & $\alpha_{7}$ & 0.0010 \\
$\mathrm{C}_{3} \mathrm{H}_{8}$ & Propane & $\alpha_{8}$ & 0.0029 \\
$\mathrm{C}_{6} \mathrm{H}_{6}$ & Benzene & $\alpha_{9}$ & 0.0010 \\
$\mathrm{C}_{7} \mathrm{H}_{8}$ & Toluene & $\beta_{2}$ & 0.0012 \\
$\mathrm{C}_{8} \mathrm{H}_{10}$ & Ethyl benzene & $\beta_{3}$ & 0.0003 \\
$\mathrm{C}_{8} \mathrm{H}_{10} \mathrm{O}_{4}$ & Primary Tar & $\tau_{1}$ & 0.5909 \\
$\mathrm{C}$ & Char & $\gamma$ & 0.0820 \\
\hline
\end{tabular}


Table 5

Mass stoichiometric coefficients of the tar cracking reaction in GASPAR.

\begin{tabular}{llll}
\hline Formula & Name & Coefficient & Value \\
\hline $\mathrm{H}_{2}$ & Hydrogen & $\omega_{1}$ & 0.0011 \\
$\mathrm{CO}$ & Carbon monoxide & $\omega_{2}$ & 0.5009 \\
$\mathrm{CO}_{2}$ & Carbon dioxide & $\omega_{3}$ & 0.1243 \\
$\mathrm{CH}_{4}$ & Methane & $\omega_{4}$ & 0.0689 \\
$\mathrm{C}_{2} \mathrm{H}_{4}$ & Ethylene & $\omega_{5}$ & 0.1554 \\
$\mathrm{C}_{2} \mathrm{H}_{6}$ & Ethane & $\omega_{6}$ & 0.0555 \\
$\mathrm{C}_{6} \mathrm{H}_{6}$ & Benzene & $\omega_{7}$ & 0.0772 \\
$\mathrm{C}_{2} \mathrm{H}_{2}$ & Acetylene & $\omega_{8}$ & 0.0176 \\
\hline
\end{tabular}

described by single step reactions, reducing their inherent mecha nism complexity, which is not the focus of the present work.

The dynamics of the pyrolysis and tar cracking reactions were modeled following first order differential equations that read:

$$
\begin{aligned}
& \frac{d m_{\text {dry biomass }}}{d t} \quad m_{\text {dry biomass }} k_{\text {pyro }} \quad m_{\text {dry biomass }} A_{\text {pyro }} \exp \left(\frac{E a_{\text {pyro }}}{R T}\right) \\
& \frac{d m_{\text {Tar }}}{d t} \quad m_{\text {Tar }} k_{\text {crack }} \quad m_{\text {Tar }} A_{\text {crack }} \exp \left(\frac{E a_{\text {crack }}}{R T}\right)
\end{aligned}
$$

The biomass pyrolysis reaction kinetic parameters were taken from the study of Gorton and Knight [7], as they were determined for beech wood in a similar temperature range in an EFR. The cracking reaction kinetic parameters were determined so that model results best fit experimental ones. The obtained values for pre exponential factor and activation energy were respectively $1.0010^{7} \mathrm{~s}^{1}$ and $32,300 \mathrm{~J} / \mathrm{mol}$.

\section{Results and discussion}

\subsection{Pyrolysis experiments in the DTR}

\subsubsection{Description of an experimental pyrolysis run}

Each experiment lasted from 20 to $90 \mathrm{~min}$. The product gas spe cies concentrations were constant along the pyrolysis run, which attested for stationary regime. It has to be noted that even for the longest experiment, the recovered quantities of bio oil and char did not exceed a few tens of grams. Hence, a few unrecovered grams of pyrolysis products can significantly impact the mass bal ance. The experimental error in the mass balance calculation was estimated at about $\pm 10 \%$.

\subsubsection{Pyrolysis products distribution and mass balance}

Table 6 shows the pyrolysis product distribution as a function of temperature (T), particle size (PS) and gas residence time (GRT). The mass balance for the different pyrolysis runs varies between $88 \%$ and $104 \%$. Considering the relatively small product masses in the pyrolysis runs, these mass balances are good ones and witness of the reliability of the experimental device and procedure.

The lowest temperature of $450{ }^{\circ} \mathrm{C}$ corresponds to the highest amount of residual solid ( $40.6 \mathrm{wt} . \%)$ and the lowest amount of gas (6.1 wt.\%). At the highest temperature of $600{ }^{\circ} \mathrm{C}$, the production of gas is maximum at $51.5 \mathrm{wt} . \%$, while that of the residual solid is at its minimum of $8.2 \mathrm{wt} . \%$. The production of bio oil reaches a max imum of $62.4 \mathrm{wt} . \%$ at $500{ }^{\circ} \mathrm{C}$ and decreases to $39.7 \mathrm{wt} . \%$ at $600{ }^{\circ} \mathrm{C}$. These results concerning the influence of temperature on product yields are globally in agreement with the above mentioned results from literature $[8,9,11,13,14]$. Our results can be explained by a low pyrolysis reaction rate at $450{ }^{\circ} \mathrm{C}$ leading to a high residual solid amount with incompletely reacted wood at the reactor exit, which is confirmed by TGA tests presented below in Section 3.1.4. Increasing the temperature accelerates the pyrolysis reaction rate and leads to higher gas and bio oil amounts, and a lower residual solid amount. In parallel to the pyrolysis reaction, the rate of con densable species cracking increases with temperature leading to a higher gas proportion and a lower bio oil one beyond $500{ }^{\circ} \mathrm{C}$.

Increasing the particle size from $370 \mu \mathrm{m}$ to $640 \mu \mathrm{m}$ induces a decrease of the bio oil and gas yields, respectively from 48.3 to $34.8 \mathrm{wt} . \%$, and from 25.6 to $11.1 \mathrm{wt} . \%$. The residual solid yield increases from 10.3 to 35 wt.\%. This general influence of particle size on the product yields was also observed by other authors $[8,11,12]$. It was suggested to be linked to the lower residence time of larger particles in the reactor, as they fall more rapidly in the reactor [8]. This hypothesis will be confirmed and investigated in more details in the modeling section.

Gas residence time does not strongly impact the pyrolysis pro duct distribution yields in the range of tested values. Indeed, as shown later, the solid residence time a few seconds is much lower than the gas residence time and thus probably principally controls the product formation.

\subsubsection{Dry gas yields}

The different species concentrations in the pyrolysis gas are given for each test in Table 7, as well as the total volume of gas, so that the yield of each species can be easily calculated.

The major gas species in the pyrolysis gas are $\mathrm{CO}, \mathrm{CO} 2, \mathrm{CH} 4, \mathrm{H} 2$ and $\mathrm{C} 2 \mathrm{H} 4$ accounting for at least $97 \mathrm{~mol} \%$ of the pyrolysis gas. The $\mathrm{CO}$ concentration in the pyrolysis gas varies between $50 \mathrm{~mol} . \%$ at $450{ }^{\circ} \mathrm{C}$ and $61 \mathrm{~mol} \%$, which is the maximum value obtained in Run $550^{\circ} \mathrm{C}$. Except from Run $450^{\circ} \mathrm{C}$, for which the $\mathrm{CO} 2$ concentra tion is around $41 \mathrm{~mol} \%$, the $\mathrm{CO} 2$ concentration in the pyrolysis dry gas varies between 15 mol.\% and 23 mol.\%. The high CO2 concen tration observed in Run $450{ }^{\circ} \mathrm{C}$ is probably due to the incomplete pyrolysis reaction and the major emission of $\mathrm{CO} 2$ in the early stages of pyrolysis. Also, reverse water gas shift is thermodynami cally favored at lower temperature, and this can be one reason explaining the higher $\mathrm{CO} 2$ content at $450{ }^{\circ} \mathrm{C}$.

The lowest $\mathrm{CO}_{2}$ concentrations correspond to the conditions favoring a complete pyrolysis reaction (temperature beyond $550{ }^{\circ} \mathrm{C}$ and smallest particle size of $370 \mu \mathrm{m}$ ). Methane concentra tion is relatively constant at around 10 mol.\%, except from Run $450{ }^{\circ} \mathrm{C} . \mathrm{H}_{2}$ concentration in the pyrolysis gas is only impacted by the temperature as it increases from $1.7 \mathrm{~mol} . \%$ at $450{ }^{\circ} \mathrm{C}$ to $12.7 \mathrm{~mol} . \%$ at $600{ }^{\circ} \mathrm{C} . \mathrm{C}_{2} \mathrm{H}_{4}$ concentration is also sensitive to the

Table 6

Pyrolysis products distribution as a function of the experimental conditions.

\begin{tabular}{llll}
\hline Pyrolysis run & Residual solid [wt.\% arb] & Bio-oil [wt.\% arb] & Permanent gases [wt.\% arb] \\
\hline Run- $4500^{\circ} \mathrm{C}$ & 40.6 & 47.5 & 6.1 \\
Run-500 ${ }^{\circ} \mathrm{C}$ & 13.6 & 62.4 & 15 \\
Run-550 ${ }^{\circ} \mathrm{C}$ & 10.3 & 48.3 & 25.6 \\
Run-600 ${ }^{\circ} \mathrm{C}$ & 8.2 & 39.7 & 51.5 \\
Run- $490 \mu \mathrm{m}$ & 17.4 & 46.3 & 19.9 \\
Run- $640 \mu \mathrm{m}$ & 35 & 34.8 & 11.1 \\
Run- $12.6 \mathrm{~s}$ & 10.4 & 47.5 & 31.8 \\
Run-20.6 s & 10.7 & 46.3 & 27.8 \\
\hline
\end{tabular}


Table 7

Gas species concentrations in the pyrolysis gas for the different runs [vol.\%]

\begin{tabular}{|c|c|c|c|c|c|c|c|c|}
\hline & Run $-450^{\circ} \mathrm{C}$ & Run $-500^{\circ} \mathrm{C}$ & Run $-550^{\circ} \mathrm{C}$ & Run- $600{ }^{\circ} \mathrm{C}$ & Run-490 $\mu \mathrm{m}$ & Run-640 $\mu \mathrm{m}$ & Run-12.6 s & Run-20.6 s \\
\hline $\mathrm{CO}$ & 49.8 & 58.4 & 61.0 & 55.1 & 58.5 & 55.4 & 59.9 & 60.6 \\
\hline $\mathrm{CO}_{2}$ & 40.6 & 21.9 & 15.1 & 14.2 & 18.3 & 23.4 & 16.2 & 14.6 \\
\hline $\mathrm{CH}_{4}$ & 4.78 & 10.4 & 11.9 & 11.9 & 11.1 & 9.32 & 11.4 & 11.9 \\
\hline $\mathrm{C}_{2} \mathrm{H}_{4}$ & 1.71 & 3 & 4.16 & 4.37 & 4.23 & 4.02 & 4.08 & 4.11 \\
\hline $\mathrm{C}_{2} \mathrm{H}_{2}$ & 0.06 & 0.17 & 0 & 0.28 & 0.35 & 0.4 & 0 & 0.25 \\
\hline $\mathrm{C}_{2} \mathrm{H}_{6}$ & 0.27 & 0.6 & 0.42 & 1.04 & 0.83 & 0.73 & 0.42 & 0.99 \\
\hline $\mathrm{C}_{6} \mathrm{H}_{6}$ & 0.17 & 0.24 & 0.4 & 0.32 & 0.32 & 0.33 & 0.32 & 0.36 \\
\hline $\mathrm{CH}_{3} \mathrm{OH}$ & 0.03 & 0.02 & 0 & 0 & 0 & 0 & 0 & 0 \\
\hline $\mathrm{C}_{7} \mathrm{H}_{8}$ & 0.26 & 0.24 & 0.22 & 0.13 & 0.18 & 0.25 & 0.14 & 0.18 \\
\hline $\mathrm{C}_{8} \mathrm{H}_{10}$ & 0.02 & 0.05 & 0 & 0 & 0 & 0 & 0 & 0 \\
\hline Total gas volume [Nl/kg (d.b)] & 40.7 & 113.1 & 208.5 & 447.6 & 158 & 84.7 & 258.6 & 227.4 \\
\hline
\end{tabular}

temperature. It increases from $1.7 \mathrm{~mol} . \%$ at $450{ }^{\circ} \mathrm{C}$ to $4 \mathrm{~mol} . \%$ at $550{ }^{\circ} \mathrm{C}$ and stabilizes at this values.

\subsubsection{Pyrolysis extent of the biomass particles}

Observation of the solid particles collected at the reactor exit showed the presence of incompletely pyrolysed particles, espe cially at low temperatures and for larger particle size. Thermo gravimetric analysis of the collected solid particles was used to quantify the pyrolysis conversion level of the particles. The mass loss plots are shown in Supplementary Material (Fig. S1).

The particle pyrolysis extent in the DTR experiments was then estimated from the sample mass loss for each temperature and particle size (Table 8 ). At $450^{\circ} \mathrm{C}$, the biomass pyrolysis advance ment is only $69 \%$ at the reactor exit. The pyrolysis extent increases significantly with temperature to reach $94 \%$ at $500{ }^{\circ} \mathrm{C}$, and $97 \%$ at $600^{\circ} \mathrm{C}$. It significantly decreases as particle size increases from $97 \%$ for the $370 \mu \mathrm{m}$ particles to $72 \%$ for the $640 \mu \mathrm{m}$ particles at the same temperature of $550{ }^{\circ} \mathrm{C}$. Altogether, these data show the significant impact of the reactor temperature and biomass particle size on the achievement of the pyrolysis reaction. Moreover, the pyrolysis advancement can be observed to vary inversely to the char yield, which seems to confirm that the higher char yield val ues measured at the lowest temperature or for the largest particles are due to biomass incomplete pyrolysis.

\subsection{Pyrolysis product composition and properties}

\subsubsection{Ultimate analysis of bio oil, gas and residual solid}

The ultimate analyses of the pyrolysis products obtained in the different runs are presented on the ternary diagram in Fig. 2. The parent beech wood composition is also indicated to support inter pretation. The results are given on an ash free basis. The oxygen content is obtained by subtraction. The elemental composition were determined for isolated or mixed bio oil fractions (Run $450{ }^{\circ} \mathrm{C}$ ). Gas elemental composition is calculated from gas yields and composition given by the $\mu \mathrm{GC}$ analysis (Section 3.1.3).

The elemental compositions of the bio oil organic fractions are very similar and very close to that of the parent wood sample. Their $\mathrm{H}$ content is about $50 \mathrm{~mol} . \%$, the $\mathrm{C}$ content about $30 \mathrm{~mol} . \%$

Table 8

Estimation of the biomass pyrolysis extent during the DTR experiments.

\begin{tabular}{|c|c|c|c|c|}
\hline Pyrolysis run & $\mathrm{Y}_{\mathrm{DTR}}[-]$ & $\% W_{\text {loss TG }}[\%]$ & $\mathrm{Y}_{\mathrm{f}}[-]$ & $\mathrm{X}[\%]$ \\
\hline Run- $450{ }^{\circ} \mathrm{C}$ & 0.406 & 66.8 & 0.135 & 68.7 \\
\hline Run $-500^{\circ} \mathrm{C}$ & 0.136 & 40.2 & 0.081 & 94.1 \\
\hline Run- $550^{\circ} \mathrm{C}$ & 0.103 & 29.3 & 0.073 & 96.8 \\
\hline Run- $600^{\circ} \mathrm{C}$ & 0.082 & 18.7 & 0.067 & 98.4 \\
\hline Run-490 $\mu \mathrm{m}$ & 0.174 & 58.6 & 0.072 & 89.0 \\
\hline Run-640 $\mu \mathrm{m}$ & 0.35 & 71.4 & 0.1 & 72.2 \\
\hline
\end{tabular}

and the $\mathrm{O}$ content about 20 mol.\%. The aqueous fractions contain less $\mathrm{C}$ and more $\mathrm{H}$ and $\mathrm{O}$ due to their high water content. Their molar composition is also relatively constant in all conditions except from Run $600^{\circ} \mathrm{C}$ for which the water content is higher.

The $C$ content of the char increases with temperature, while $O$ and $\mathrm{H}$ contents decrease due to their emission to the gas phase. Chars of Run $450^{\circ} \mathrm{C}$, Run $490 \mu \mathrm{m}$ and Run $640 \mu \mathrm{m}$, show a higher $\mathrm{O}$ content and a lower $\mathrm{C}$ one due to incomplete pyrolysis reaction and to a higher proportion of wood in the recovered solid. Similarly to results obtained at higher temperature [27], it can be observed that all the points representing the solid elemental composition are found in the same straight line which connects the solid com position of the parent beech wood and the solid composition when pyrolysis is finished.

The $\mathrm{C}$ content in the pyrolysis gas is relatively constant at about 36 mol.\%. The 0 content decreases as temperature increases, while the $\mathrm{H}$ content increases from $14 \mathrm{~mol}$ \% to $36 \mathrm{~mol}$ \% when increasing the temperature from $450{ }^{\circ} \mathrm{C}$ to $600{ }^{\circ} \mathrm{C}$. Only small variations are observed when varying the particle size or the gas residence time.

Balances for $\mathrm{C}$ and $\mathrm{H}$ elements recovered in char, bio oil, water and gas lie between $80 \%$ and $91 \%$ for $\mathrm{C}$ and $91 \%$ and $110 \%$ for $\mathrm{H}$, which is relatively satisfactory.

\subsubsection{HHV of bio oil, residual solid and gas}

The HHV of 20 samples including 8 residual solids, 5 organic fractions, 5 aqueous fractions, the bio oil of Run $450{ }^{\circ} \mathrm{C}$ and the parent wood were measured with the bomb calorimeter and are plotted in Fig. 3. The quantities of the aqueous fractions of Run $600{ }^{\circ} \mathrm{C}$ and Run $12.6 \mathrm{~s}$ were not sufficient to allow HHV measure ments. Sheng et al. [28] set a correlation to estimate the HHV of biomass from their proximate and ultimate analyses. However, this correlation did not fit very well to our own measurements, maybe because they concerned products from biomass pyrolysis and not raw biomass. We then decided to set our own correlation on the basis of the measured HHVs of 20 samples and of their analyses, and to extend it for the prediction of the unknown HHVs. Most of the time, this correlation predicts the HHV with less than 5\% error; it was used to calculate the HHV of the aqueous fractions of Run $600{ }^{\circ} \mathrm{C}$ and Run $12.6 \mathrm{~s}$. The modeled HHV expression reads:

$$
H H V_{i}^{\text {model }} \quad a+b \% C_{i}+c \% H_{i}+d \% O_{i}
$$

Where $\% C_{i}, \% H_{i}$, and $\% O_{i}$ are respectively the mass fractions (d.b) of carbon, hydrogen and oxygen in the compound " $i$ ". The coefficients $a, b, c$ and $d$ were determined by the minimization of the following objective function:

OF $\quad \sum_{i=1}^{n}\left(H H V_{i}^{\exp } \quad H H V_{i}^{\text {model }}\right)^{2}$ 


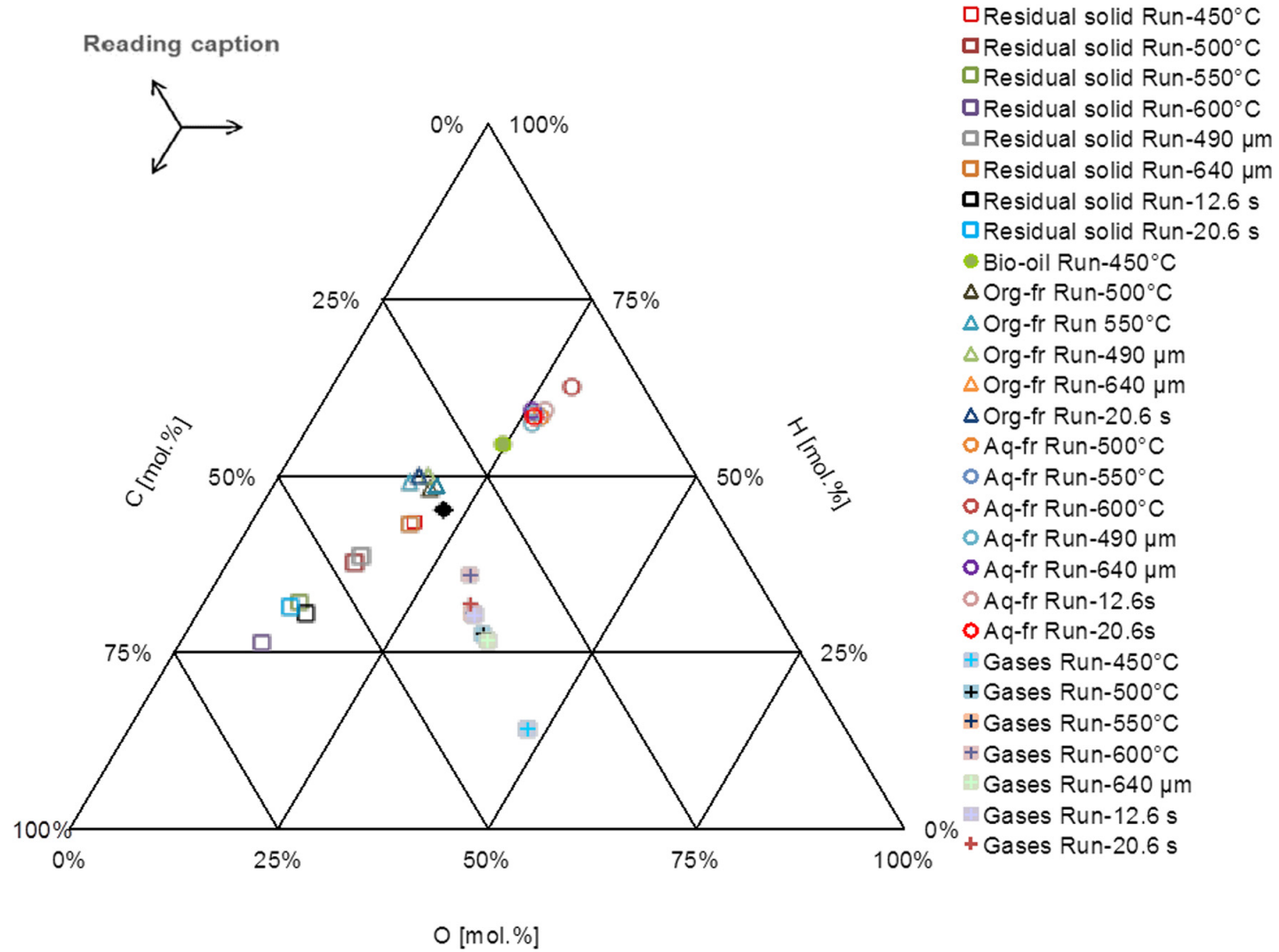

Fig. 2. Elemental composition of the products of beech sample pyrolysis for the different experimental conditions.

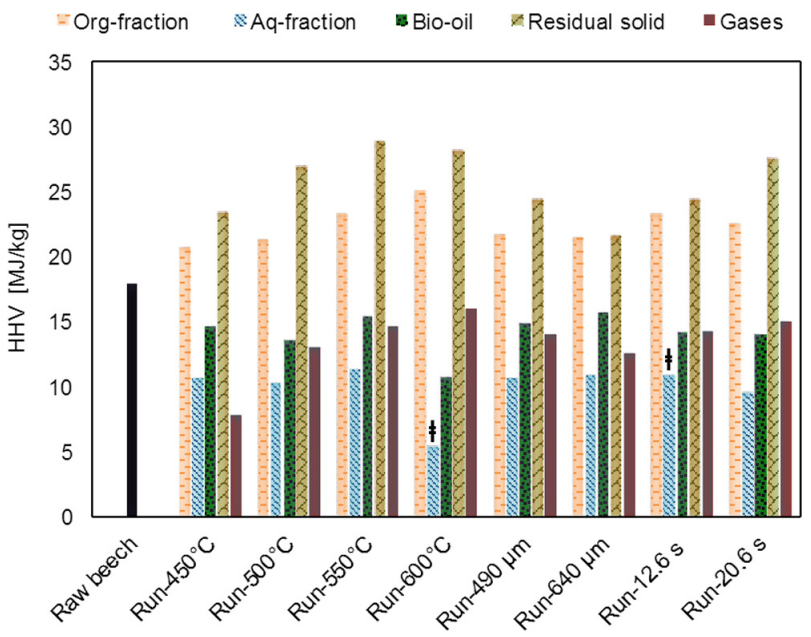

Fig. 3. HHV of wood and pyrolysis products ( $\$$ : calculated with the model).

Where $H H V_{i}^{\exp }$ is the experimental HHV of the compound " $i$ ", and $n$ is the number of experimental points (20 in the present case). The values for $a, b, c$ and $d$ obtained after the minimization procedure are respectively: $72.06,1.12,1.34$ and 0.66 .

The residual solid HHV is higher than that of bio oil and gas. It lies between 23 and $29 \mathrm{MJ} / \mathrm{kg}$ and is close to that of carbon $\left(32.8 \mathrm{MJ} / \mathrm{kg}\right.$ ). The highest value was obtained for Run $550^{\circ} \mathrm{C}$. The HHV of organic fraction of bio oils ranges between 21 and $25 \mathrm{MJ} /$ $\mathrm{kg}$. The maximum value was obtained at $600^{\circ} \mathrm{C}$, temperature at which the water content is the lowest. The HHV of gas lies between $8 \mathrm{MJ} / \mathrm{kg}$ (Run $450^{\circ} \mathrm{C}$ ) and $16 \mathrm{MJ} / \mathrm{kg}$ (Run $600^{\circ} \mathrm{C}$ ). It increases with temperature due to the decrease of the $\mathrm{CO}_{2}$ concentration and the increase of $\mathrm{H}_{2}$ concentration in the pyrolysis gas. As expected, the lowest HHV is that of the aqueous fraction, which is in the range of $511 \mathrm{MJ} / \mathrm{kg}$. This is due of course to its high water content. Know ing the relative fractions of the organic and aqueous phases, the HHV of bio oil can be calculated and is found to lie between $11 \mathrm{MJ} / \mathrm{kg}$ (at $600{ }^{\circ} \mathrm{C}$ ) and $16 \mathrm{MJ} / \mathrm{kg}$. Excluding Run $600^{\circ} \mathrm{C}$ result, the average bio oil HHV for the 7 runs is $14.6 \pm 0.8 \mathrm{MJ} / \mathrm{kg}$, which is in agreement with common values presented in the literature for bio oils obtained by biomass pyrolysis [29]. Thus, under $600^{\circ} \mathrm{C}$, the temperature, gas residence time and particle size do not have any significant influence on bio oil HHV.

From these HHV data and pyrolysis product yields, the energy recovered in the different pyrolysis products can be calculated. The energy recovered in the bio oil lies between $22 \%$ and $44 \%$ of the initial chemical energy content of the parent wood. The maxi mum value is for Run $500^{\circ} \mathrm{C}$; this test thus corresponds to the optimal conditions for maximum bio oil yield and energy recovery in the bio oil. The chemical energy balance value lies between 78 and $95 \%$.

3.2.3. Water fraction, acidity and chemical analysis of the bio oils 3.2.3.1. Water content of bio oils. The aqueous fraction of the bio oil recovered in the cold trap is always higher than the organic frac tion (Table 9). It represents 58 to $80 \mathrm{wt} \%$ of the total bio oil. The name "aqueous fraction" makes sense when looking at its water content, which is about $42 \mathrm{wt} . \%$ for all runs except Run $600{ }^{\circ} \mathrm{C}$ for which it reaches $62 \mathrm{wt} . \%$. The water content of the organic fraction varies between 7 and 20\% with an average of 11.3 wt.\%. 
Table 9

Mass fractions, water content and TAN of the aqueous and organic phases of the bio-oils.

\begin{tabular}{|c|c|c|c|c|c|c|c|}
\hline \multirow[t]{2}{*}{ Pyrolysis Run } & \multicolumn{2}{|c|}{$\begin{array}{l}\text { Fraction of the } \\
\text { total bio-oil [wt.\%] }\end{array}$} & \multicolumn{2}{|c|}{$\% \mathrm{H}_{2} \mathrm{O}$} & \multirow[t]{2}{*}{ Water free bio-oil yield [wt.\% biomass db] } & \multicolumn{2}{|c|}{$\begin{array}{l}\text { TAN [mg KOH/g } \\
\text { bio-oil] }\end{array}$} \\
\hline & $\mathrm{AF}$ & OF & $\mathrm{AF}$ & $\mathrm{OF}$ & & $\mathrm{AF}$ & $\mathrm{OF}$ \\
\hline Run $-450^{\circ} \mathrm{C}$ & 62 & 38 & 45 & 21 & 33.6 & 129 & 119 \\
\hline Run- $500^{\circ} \mathrm{C}$ & 72 & 28 & 45 & 11 & 44.6 & 116 & 98 \\
\hline Run $-550^{\circ} \mathrm{C}$ & 70 & 30 & 42 & 9.8 & 36.5 & 122 & 45 \\
\hline Run- $600{ }^{\circ} \mathrm{C}$ & 76 & 24 & 62 & 7.8 & 22.8 & 87 & 46 \\
\hline Run-490 $\mu \mathrm{m}$ & 65 & 35 & 39 & 11 & 35.0 & 120 & 124 \\
\hline Run-640 $\mu \mathrm{m}$ & 58 & 42 & 43 & 12 & 25.9 & 140 & 119 \\
\hline Run-12.6s & 80 & 20 & 42 & 7.5 & 35.8 & 110 & 46 \\
\hline Run-20.6 s & 69 & 31 & 43 & 11 & 36.3 & 118 & 115 \\
\hline
\end{tabular}

Altogether, these data give water contents of the bio oil between $28 \mathrm{wt} . \%$ and $47 \mathrm{wt} . \%$. The average water content for the 8 runs is $34 \%$, which is close to values found in the literature [30]. The max imum bio oil yield of $62.4 \mathrm{wt} . \%\left(500^{\circ} \mathrm{C} 315450 \mu \mathrm{m} \quad 16.6 \mathrm{~s}\right)$ thus includes about $44 \mathrm{wt} . \%$ (dry biomass basis) of water free bio oil, commonly called "tars".

3.2.3.2. Total acid number of bio oils. The acidity of bio oils is an important parameter linked to the storage safety as well as to the pipe and container corrosion. The acidity of pyrolysis liquids is high due to the elevated content ( $810 \mathrm{wt} . \%)$ of volatile acids (mainly acetic and formic acid), which constitute, with water, the main cause for the corrosiveness of pyrolysis bio oils [29].

TAN of the different bio oils is shown in Table 9. TAN of aqueous fraction lies between 87 and $140 \mathrm{mg} \mathrm{KOH} / \mathrm{g}$. Organic fraction TAN ranges between 44 and $123 \mathrm{mg} \mathrm{KOH} / \mathrm{g}$. In each test, the aqueous fraction TAN is higher than the organic fraction one. Moreover, TAN decreases as temperature increases for the two phases, and is reduced by a 3 factor from $450^{\circ} \mathrm{C}$ to $600^{\circ} \mathrm{C}$. This can be corre lated to the decrease of the acid content of bio oils. TAN of organic phase is almost insensitive to the variation of biomass particle size and gas residence time.

Nevertheless, the TAN variations with temperature turn out to be negligible when considering a more familiar scale of acidity measurement, namely $\mathrm{pH}$. Bunting and Boyd [31] have correlated the TAN values obtained in a wide range to those of $\mathrm{pH}$. Using their correlation, the $\mathrm{pH}$ was found to be relatively constant for all bio oils, between 2.8 and 3 which is typical of pyrolysis oils [29]. It can be concluded that the experimental conditions do not have any sig nificant influence on the corrosiveness of the bio oils.

3.2.3.3. Chemical analysis of bio oils. Ten molecules were quantified by GC FID in the bio oils obtained in the six runs for which the reactor temperature and particle sizes were varied. The different species concentrations are summarized in Table 10.
Glycoaldehyde, hydroxyacetone and acetic acid are the major components. Glycoaldehyde concentration shows a peak at $500^{\circ} \mathrm{C}$. It then decreases as temperature increases, probably due to secondary cracking reactions. Concentrations of hydroxyacetone (around $20 \mathrm{~g} / \mathrm{kg}$ of bio oil) and acetic acid (70 $80 \mathrm{~g} / \mathrm{kg}$ of bio oil) are relatively constant in the tested temperature range. Propanoic acid concentration in the bio oil increases linearly with tempera ture, from $1.6\left(450^{\circ} \mathrm{C}\right)$ to $10.4 \mathrm{~g} / \mathrm{kg}\left(600^{\circ} \mathrm{C}\right)$. Concentration of phe nol increases with temperature from 0.3 to $5.1 \mathrm{~g} / \mathrm{kg}$. This may be related to the thermal cracking of guaiacol, which loses the meth oxy group to be converted into phenol. The concentration of levoglucosan increases with temperature from $0.11 \mathrm{~g} / \mathrm{kg}$ at $450{ }^{\circ} \mathrm{C}$ to $1.7 \mathrm{~g} / \mathrm{kg}$ at $600{ }^{\circ} \mathrm{C}$.

The concentrations of acetic acid, glycoaldehyde, hydroxyace tone and guaiacol respectively increase from 71 to $176 \mathrm{~g} / \mathrm{kg}$, from 125 to $188 \mathrm{~g} / \mathrm{kg}$, from 71 to $176 \mathrm{~g} / \mathrm{kg}$ and from 2.4 to $7.5 \mathrm{~g} / \mathrm{kg}$ when increasing the particle size from $370 \mu \mathrm{m}$ to $640 \mu \mathrm{m}$. A very sharp increase in the levoglucosan concentration from 1.8 to $61 \mathrm{~g} / \mathrm{kg}$ is also noticed when increasing the particle size. Formaldehyde fol lows the reverse trend with its concentration decreasing when increasing the particle size. In the literature on DTR pyrolysis (see introduction), the influence of particle size on bio oil compo nents speciation was not investigated. The big influence of particle size on bio oil components in our experiments is probably not linked to the particle size itself but rather to its consequence: as particle size increases, the biomass particle pyrolysis extent decreases (Section 3.1.4) which means that the particle is still undergoing pyrolysis when it leaves the reactor. The high concen trations of some species found in the bio oil of Run $640 \mu \mathrm{m}$ (espe cially levoglucosan or acetic acid) can thus be correlated to the initial stages of pyrolysis. Indeed, according to [32], levoglucosan is emitted during the very first stages of the cellulose pyrolysis reaction. Yields of acetic acid of about 5 wt.\% were reported in beech wood torrefaction around $300{ }^{\circ} \mathrm{C}$ [33]. As the reaction is rapidly quenched due to the low particle residence time in the

Table 10

Yields [g/ kg of bio-oil] of 10 molecules in bio-oils obtained for different temperatures and wood particle sizes.

\begin{tabular}{|c|c|c|c|c|c|c|}
\hline & Run- $450^{\circ} \mathrm{C}$ & Run- $500^{\circ} \mathrm{C}$ & Run- $550^{\circ} \mathrm{C}$ & Run- $600{ }^{\circ} \mathrm{C}$ & Run-490 $\mu \mathrm{m}$ & Run-640 $\mu \mathrm{m}$ \\
\hline Formaldehyde & 0.8 & 0.9 & 0.8 & 3 & 0.2 & 0.1 \\
\hline Glycolaldehyde & 23 & 135 & 126 & 58 & 160 & 188 \\
\hline Acetic acid & 84 & 68 & 71 & 74 & 102 & 176 \\
\hline Hydroxyacetone & 26 & 26 & 31 & 25 & 33 & 52 \\
\hline Propanoic acid & 1.6 & 4.2 & 7.3 & 10.4 & 6.2 & 8.3 \\
\hline Phenol & 0.3 & 0.6 & 1.9 & 5.1 & 1.6 & 3.4 \\
\hline Guaiacol & 3.5 & 2.8 & 2.4 & 2.6 & 2.7 & 7.5 \\
\hline Eugenol & 0.2 & 0.3 & 0.1 & 0.2 & 0.1 & 0.6 \\
\hline Isoeugenol & 0.1 & 0.2 & 0.2 & 0.1 & 0.1 & 5.6 \\
\hline Levoglucosan & 0.1 & 0.7 & 1.8 & 1.7 & 3.7 & 60 \\
\hline Total & 139 & 239 & 242 & 181 & 309 & 501 \\
\hline
\end{tabular}


reactor, levoglucosan and acetic acid contents in the bio oil are then high.

\subsection{Modeling results with GASPAR}

\subsubsection{Comparison between model and experimental results}

In the present section, we aim at providing a better under standing of biomass particle pyrolysis in the DTR. The comparison between the experimental pyrolysis product yields and those given by the model in the tested temperature and particle size ranges are shown respectively in Fig. 4 and Fig. 5 (main products) and in Supplementary Material (Figs. S2 and S3) for minor products. It has to be noted that the experimental tar yields correspond to the water free bio oil yields. The experimental water yields correspond to the sum of water present in the raw biomass as moisture and the water produced by the pyrolysis reaction. A relative error of $10 \%$ is considered for the average particle size estimation.

Fig. 4 shows that, despite of some discrepancies, the model cor rectly represents the trend of the major product yields (char, tar, $\mathrm{CO}, \mathrm{CO}_{2}, \mathrm{H}_{2} \mathrm{O}$ and $\mathrm{CH}_{4}$ ) as a function of temperature for a particle size of $370 \mu \mathrm{m}$. As the experimental mass balances are different from $100 \%$, and the tar yield stoichiometry of the model is obtained by difference after fixing the stoichiometry of the char and gases, the discrepancies between the simulated yields and the experi mental ones are unavoidable. The model does not accurately describe the evolution of minor pyrolysis gas species. We estimate, however, that the actual degree of precision is satisfactory for engi neering purposes.

As shown in Fig. 5, the model well represents the global trends of the main pyrolysis product yields, but the yields are not accu rately predicted for the larger particle sizes, especially for tar and solid residue yields with $490 \mu \mathrm{m}$ particles, and solid residue yield with $640 \mu \mathrm{m}$ particles. Nevertheless, the major gas species yields, i.e. $\mathrm{CO}, \mathrm{CO}_{2}, \mathrm{H}_{2} \mathrm{O}$ and $\mathrm{CH}_{4}$ are well predicted by the model, but not the minor ones. These results demonstrate that the model assumptions may be valid only over defined temperature and par ticle size ranges.

Estimations of the dimensionless pyrolysis number Py, defined as the ratio between pyrolysis reaction characteristic time and internal heat conduction one [34], were performed. The pyrolysis number should be higher than about 10 to ensure a chemistry controlled regime and thus a homogeneous particle temperature. At $550{ }^{\circ} \mathrm{C}$, the Py number was estimated at 7,4 and 2 for a particle
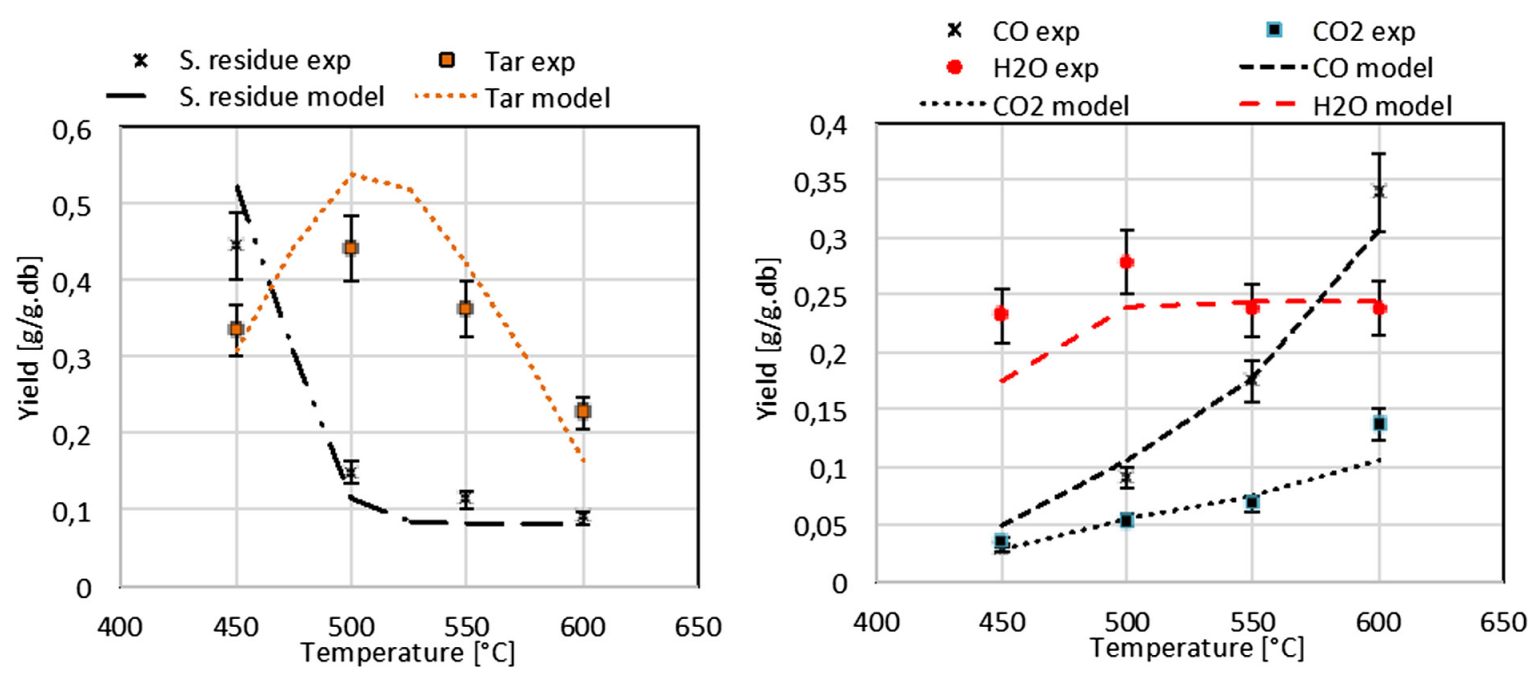

Fig. 4. Comparison between the experimental yields and modeled ones for the different reaction temperatures (PS $=370 \mu \mathrm{m})$.
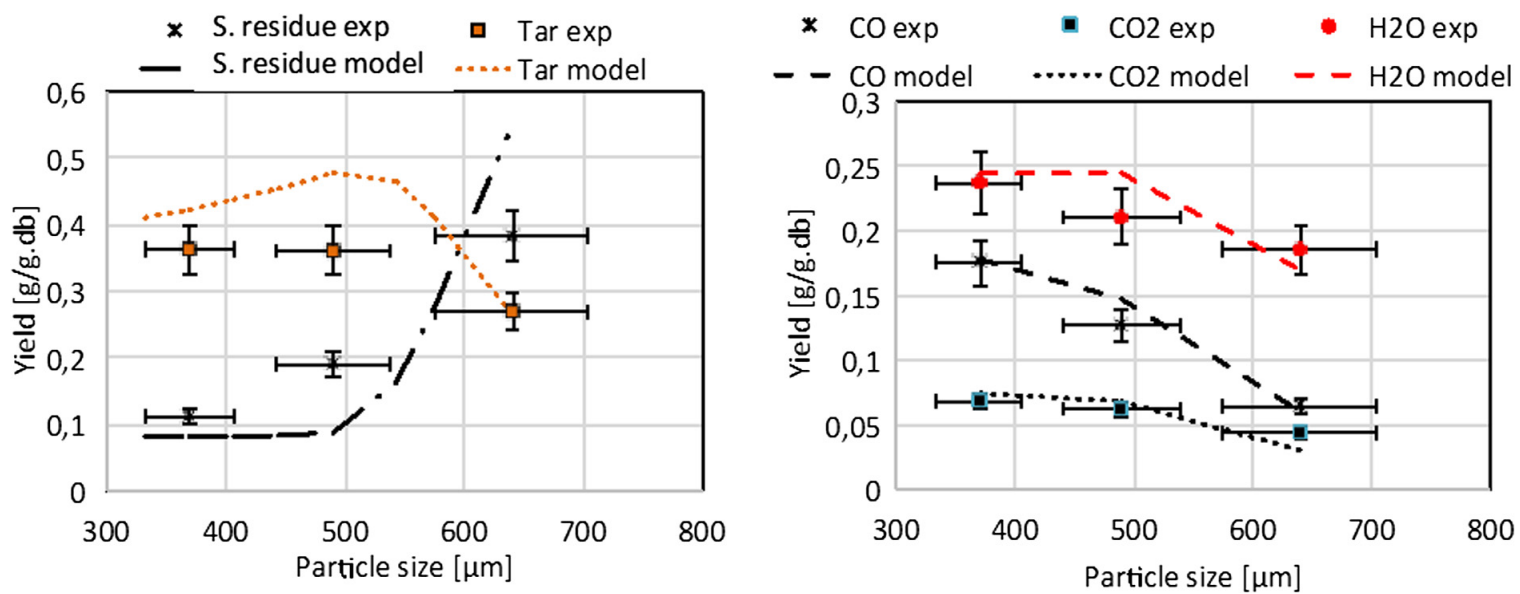

Fig. 5. Comparison between the experimental yields and modeled ones for the different particle sizes $\left(\mathrm{T}=550{ }^{\circ} \mathrm{C}\right)$. 
size of $370 \mu \mathrm{m}, 490 \mu \mathrm{m}$ and $640 \mu \mathrm{m}$ respectively. For a particle size of $370 \mu \mathrm{m}$, Py was estimated at 43, 17, 7 and 4 respectively at $450{ }^{\circ} \mathrm{C}, 500^{\circ} \mathrm{C}, 550^{\circ} \mathrm{C}$ and $600^{\circ} \mathrm{C}$. Thus, the chemically controlled regime assumption can be criticized at $550^{\circ} \mathrm{C}$ for the higher parti cle sizes, and above $550{ }^{\circ} \mathrm{C}$ for the smaller particle size. However, as a first approach, this simplified model has been used to get a better understanding of the pyrolysis and cracking reaction extents along the reactor.

\subsubsection{Discussion}

The pyrolysis extent is directly related to the particle tempera ture and residence time. Fig. 6 shows the evolution of the simulated particle temperature, slip velocity and residence time as a function of particle position in the reactor for the different pyrolysis experiments.

3.3.2.1. Influence of the reactor temperature. According to the model, the $370 \mu \mathrm{m}$ particle temperature almost reach that of the reactor after about $40 \mathrm{~cm}$ of fall in the reactor. The biomass particles reach their maximum slip velocity of about $0.65 \mathrm{~m} / \mathrm{s}$ after around $0.2 \mathrm{~s}$ regardless of the reactor temperature. The particle residence time in the reactor increases markedly with temperature from $1.7 \mathrm{~s}$ at $450{ }^{\circ} \mathrm{C}$ to $5.4 \mathrm{~s}$ at $600{ }^{\circ} \mathrm{C}$. These modeling results can be explained more in details as follows:
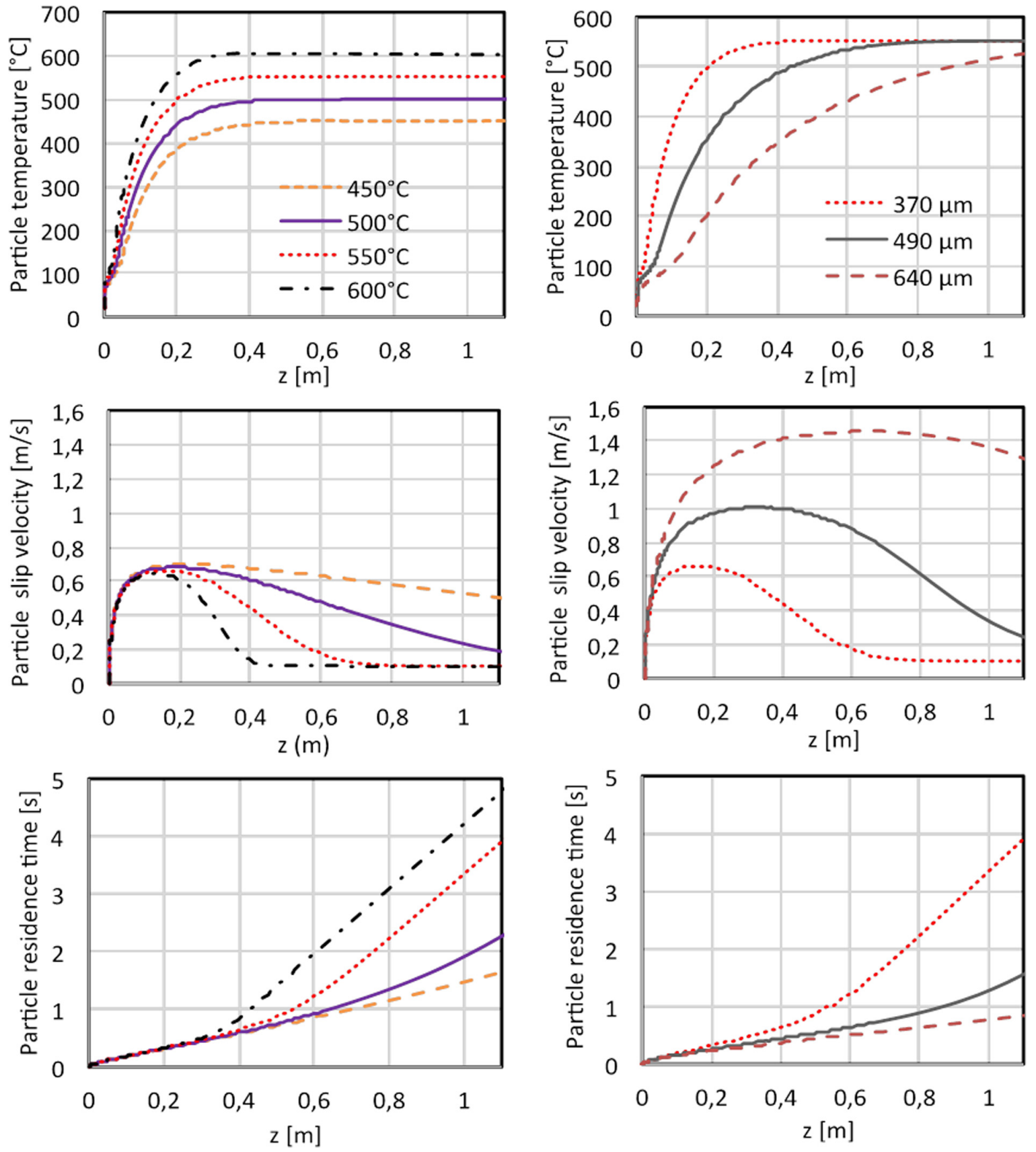

Fig. 6. Influence of the reactor temperature (right side, $P S=370 \mu \mathrm{m}$ ) and particle size (left side, $\mathrm{T}=550{ }^{\circ} \mathrm{C}$ ) on the biomass particle temperature, slip velocity and residence time. 
Simulated reactor lengths $\left(\mathrm{L}_{\mathrm{R}}\right)$ and tar yields $\left(\mathrm{Y}_{\mathrm{T}}\right)$ for a pyrolysis extent of $95 \%$ in the range of temperatures and particle sizes tested in the present work.

\begin{tabular}{|c|c|c|c|c|c|c|c|}
\hline & & \multicolumn{6}{|c|}{ Particle size $[\mu \mathrm{m}]$} \\
\hline & & \multicolumn{2}{|l|}{370} & \multicolumn{2}{|l|}{490} & \multicolumn{2}{|l|}{640} \\
\hline & & $\mathrm{L}_{\mathrm{R}}[\mathrm{m}]$ & $\mathrm{Y}_{\mathrm{T}}$ [g/g d.b] & $\mathrm{L}_{\mathrm{R}}[\mathrm{m}]$ & $\mathrm{Y}_{\mathrm{T}}$ [g/g d.b] & $\mathrm{L}_{\mathrm{R}}[\mathrm{m}]$ & $\mathrm{Y}_{\mathrm{T}}$ [g/g d.b] \\
\hline \multirow[t]{4}{*}{$\mathrm{T}_{\mathrm{R}}\left[{ }^{\circ} \mathrm{C}\right]$} & 450 & 3.6 & 0.56 & 5.75 & 0.55 & 8.1 & 0.53 \\
\hline & 500 & 1.6 & 0.54 & 2.4 & 0.52 & 3.6 & 0.49 \\
\hline & 550 & 0.79 & 0.51 & 1.35 & 0.45 & 2.13 & 0.43 \\
\hline & 600 & 0.46 & 0.47 & 0.79 & 0.42 & 1.44 & 0.32 \\
\hline
\end{tabular}

- During the first $0.2 \mathrm{~s}$, the particle temperature is not high enough to induce a significant pyrolysis reaction rate; thus the particle density remains close to that of wood. The particle slip velocity increases due to gravitational attraction. Its maximum observed after about $0.2 \mathrm{~s}$ in the reactor is almost constant whatever the reactor temperature.

- The decrease in the particle slip velocity indicates the beginning of the pyrolysis reaction, with gas emission and transformation of the wood particle into char, which has a lower density and diameter, and thus a lower slip velocity. The decrease in the slip velocity occurs faster as the reactor temperature is higher, because of higher particle temperature and pyrolysis rate.

- The particle slip velocity tends towards a terminal velocity of $0.1 \mathrm{~m} / \mathrm{s}$, for which the applied forces on the particle equilibrate. This constant particle velocity is reached when the pyrolysis reaction is achieved. The particle has then completely turned into char and the particle density and diameter do no change anymore. For temperatures of $450{ }^{\circ} \mathrm{C}$ and $500{ }^{\circ} \mathrm{C}$, the particle slip velocity does not decrease to this value before leaving the reactor, which means that the pyrolysis is not yet finished at the time the particle leaves the reactor.

3.3.2.2. Influence of particle size. It can be observed on Fig. 6 that the particle temperature increases less rapidly along the reactor as the particle size increases. The mid class size particles $(490 \mu \mathrm{m})$ reach the reactor temperature near its exit only. The largest particles of $640 \mu \mathrm{m}$ leave the reactor at $500{ }^{\circ} \mathrm{C}$ only, although the reactor tem perature is $550{ }^{\circ} \mathrm{C}$. Moreover, the maximum value of the particle slip velocity increases with particle size. Hence, the particle resi dence time decreases sharply from $4.4 \mathrm{~s}$ for the smallest particles $(370 \mu \mathrm{m})$ to $0.9 \mathrm{~s}$ for the largest ones $(640 \mu \mathrm{m})$. Increasing the par ticle size implies two main changes that impact the pyrolysis rate and the particle motion:

- The rate of temperature rise decreases when increasing the par ticle size, which is related to the decrease of the particle surface to volume ratio. This directly impacts the pyrolysis rate.

- The particle slip velocity increases with particle size, which means that the residence time is lower for larger particles.

These modeling results highlight the importance of mastering the temperature and the particle size for a given reactor configura tion. Fig. S4 in Supplementary Material shows the simulation results concerning the evolution of the bio oil yield as a function of the reactor temperature and particle size. Optimal conditions for bio oil production (considering the present reactor geometry) occur in relatively narrow ranges of temperature $\left(500525^{\circ} \mathrm{C}\right.$ ) and particle size (around $300 \mu \mathrm{m}$ ).

To maximize the tar yield, the tar cracking reaction should be limited as much as possible. In order to study the extent of the tar cracking reaction, simulations were run with the tar cracking reaction being deactivated, and compared to the simulations for which this latter is activated (Fig. S5 in Supplementary Material).
The results show that tar cracking becomes significant at 550 and $600^{\circ} \mathrm{C}$, only for the smallest particles. At $600^{\circ} \mathrm{C}$, near half of tars are cracked at $\mathrm{Z} 0.8 \mathrm{~m}$. These results suggest not to go beyond $500{ }^{\circ} \mathrm{C}$ to limit the tar cracking in the actual reactor config uration. Increasing the particle size causes the tar production to shift towards higher $\mathrm{z}$ (axial position in the reactor relatively to the inlet) values due to the lower particle heating rates, inducing a lower pyrolysis rate and hence a lower tar production rate, and also cracking.

Achieving the pyrolysis reaction and limiting tar cracking so as to maximize the bio oil yields are two opposite objectives, as the former one requires high temperatures, while the latter one suffers from it. Reactor with a long length are a priori interesting as they enable to lower the reaction temperature by increasing the resi dence time. The aim here is to investigate the optimal experimen tal conditions and reactor length that would allow achieving biomass pyrolysis, and at the same time minimizing bio oil crack ing extent. By simulations, the length of the reactor for $95 \%$ bio mass conversion was determined in the range of temperature and particle size tested in the present work (Table 11). The maxi mum theoretical tar yield that can be achieved considering the sto ichiometry of the pyrolysis reaction implemented in the model is $0.59 \mathrm{~g} / \mathrm{g}$ of dry biomass. This theoretical optimum is almost reached at $450^{\circ} \mathrm{C}$, at which tar cracking is low, with required reac tor lengths increasing with particle size. The present results give first quantitative values for the design and optimization of operat ing parameters.

\section{Conclusion}

The present study investigated woody biomass fast pyrolysis in a DTR in the temperature range of $450600{ }^{\circ} \mathrm{C}$ with particle size between 370 and $640 \mu \mathrm{m}$, using both experimental and modeling approaches. Despite some discrepancies with the experimental results, the $1 \mathrm{D}$ modeling results could bring some essential infor mation on the progress of the pyrolysis reaction in the DTR. The analyses of all products char, bio oil and gas also brought infor mation on the advancement of the pyrolysis and cracking for the different tests. They showed how the particle size and reactor tem perature influenced the particle temperature and residence time in the reactor and consequently the pyrolysis extent of the particle, the tar cracking and thus the product yields.

The production of bio oil reaches a maximum of $62.4 \mathrm{wt} . \%$ (raw biomass basis) at $500^{\circ} \mathrm{C}$ for the $370 \mu \mathrm{m}$ particles. This optimal yield corresponds to $44.2 \mathrm{wt}$.\% of water free bio oil (dry biomass basis), commonly called "tars". The bio oil yield is lower at higher temperatures for a constant particle size due to tar cracking. At the optimum of bio oil production, the biomass particle conversion advancement was estimated at $94 \%$ at the reactor exit. At $550{ }^{\circ} \mathrm{C}$, increasing the particle size from $370 \mu \mathrm{m}$ to $640 \mu \mathrm{m}$ induces a decrease of the bio oil yield from 48.3 to $34.8 \mathrm{wt} . \%$, which is due incomplete pyrolysis of the particles, because of a too short resi dence time as well as a too long heating time of particles. 
Bio oil HHV and water content are impacted by the pyrolysis conditions. The best bio oil mass and thermal yields are obtained for a temperature of $500^{\circ} \mathrm{C}$ and a biomass particle size of $370 \mu \mathrm{m}$. The bio oil properties are globally similar to that of bio oils obtained in other types of reactors. Moreover, the pyrolysis conditions temperature, particle size were not found to have any significant influence on the bio oil properties, such as acidity.

The model was also used to investigate which conditions would constitute the best compromise to achieve maximum bio oil pro duction. This means that the biomass particle pyrolysis is com pleted high particle temperature/residence time enough and that tar cracking is avoided low Vapor temperature/residence time enough. For each given temperature and particle size, an opti mal reactor length could then be determined.

Despite the worthy information acquired by simulation about the pyrolysis reaction in the DTR, future improvement of the model concerning the pyrolysis reaction chemistry and spatial discretiza tion of the particles (for temperatures beyond $500{ }^{\circ} \mathrm{C}$ and particle size larger than $370 \mu \mathrm{m}$ ) are required to further enhance the model predictive ability. This model will be able to be used for the design of pilot and industrial scale pyrolysis EFRs.

\section{Acknowledgements}

The participation and financial support of the French CCIAG Company to this work is gratefully acknowledged.

The authors also thank a lot Sébastien THIERY, Hélène MILLER, Marine BLANCHIN, Suzanne ANOUTI (CEA) for their essential tech nical participation to this work.

\section{References}

[1] Meadows D, Randers J, Meadows D. Limits to Growth. The 30-Year Update. Chelsea Green Publishing; 2004.

[2] Di Blasi C. Combustion and gasification rates of lignocellulosic chars. Prog Energy Combust Sci 2009;35:121-40.

[3] Bridgwater AV. Review of fast pyrolysis of biomass and product upgrading. Biomass Bioenergy 2012;38:68-94.

[4] Bridgwater AV, Peacocke GVC. Fast pyrolysis processes for biomass. Renew Sustain Energy Rev 2000;4:1-73.

[5] Knight JA, Gorton CW, Kovac RJ. Oil production by entrained flow pyrolysis of biomass. Biomass 1984;6:69-76.

[6] Gorton CW, Kovac RJ, Knight JA, Nygaard TI. Modeling pyrolysis oil production in an entrained-flow reactor. Biomass 1990;21:1-10.

[7] Gorton CW, Knight JA. Oil from biomass by entrained-flow pyrolysis. Biotechnol Bioeng Symp 1984:15-20.

[8] Ellens CJ, Brown RC. Optimization of a free-fall reactor for the production of fast pyrolysis bio-oil. Bioresour Technol 2012;103:374-80.

[9] Gable P. The effect of process variables on pyrolysis in a freefall reactor. Iowa State University; 2014.
[10] Imran A, Bramer EA, Seshan K, Brem G. High quality bio-oil from catalytic flash pyrolysis of lignocellulosic biomass over alumina-supported sodium carbonate. Fuel Process Technol 2014:127:72-9.

[11] Li S, Xu S, Liu S, Yang C, Lu Q. Fast pyrolysis of biomass in free-fall reactor for hydrogen-rich gas. Fuel Process Technol 2004;85:1201-11.

[12] Onay O, Koçkar OM. Pyrolysis of rapeseed in a free fall reactor for production of bio-oil. Fuel 2006;85:1921-8.

[13] Pattiya A, Sukkasi S, Goodwin V. Fast pyrolysis of sugarcane and cassava residues in a free-fall reactor. Energy 2012;44:1067-77.

[14] Pidtasang B, Udomsap P, Sukkasi S, Chollacoop N, Pattiya A. Influence of alcohol addition on properties of bio-oil produced from fast pyrolysis of eucalyptus bark in a free-fall reactor. J Ind Eng Chem 2013;19:1851-7.

[15] Rabaçal M, Costa M, Vascellari M, Hasse C. Kinetic modelling of sawdust and beech wood pyrolysis in drop tube reactors using advanced predictive models. Chem Eng Trans 2014:37:79-84.

[16] Dupont C, Chen L, Cances J, Commandre J-M, Cuoci A, Pierucci S, et al. Biomass pyrolysis: Kinetic modelling and experimental validation under high temperature and flash heating rate conditions. J Anal Appl Pyrolysis 2009;85:260-7.

[17] Billaud J, Valin S, Ratel G, Peyrot M, Weiland F, Hedman H, et al. Biomass gasification in entrained flow reactor: Influence of wood particle size. Chem Eng Trans 2016;50:37-42.

[18] Dupont C, Commandré J-M, Gauthier P, Boissonnet G, Salvador S, Schweich D, et al. Biomass pyrolysis experiments in an analytical entrained flow reactor between $1073 \mathrm{~K}$ and $1273 \mathrm{~K}$. Fuel 2008;87:1155-64.

[19] Septien S, Valin S, Dupont C, Peyrot M, Salvador S. Effect of particle size and temperature on woody biomass fast pyrolysis at high temperature [1000$\left.1400^{\circ} \mathrm{C}\right]$. Fuel 2012:97:202-10.

[20] Taillet R, Febvre P, Villain L. Dictionnaire de physique. De Boeck Supérieur; 2009.

[21] Mullen CA, Boateng AA. Chemical composition of bio-oils produced by fast pyrolysis of two energy crops. Energy Fuels 2008;22:2104-9.

[22] Chen L. Fast pyrolysis of millimetric wood particles between $800^{\circ} \mathrm{C}$ and $1000^{\circ} \mathrm{C}$ PhD thesis. Université Claude Bernard - Lyon 1; 2009.

[23] Turton R, Levenspiel O. A short note on the drag correlation for spheres. Powder Technol 1986;47:83-6.

[24] Billaud J. Gazéification de biomasse en réacteur à flux entrainé: étude expérimentales et modélisation PhD thesis. Université de Toulouse; 2015.

[25] Septien S, Valin S, Peyrot M, Spindler B, Salvador S. Influence of steam on gasification of millimetric wood particles in a drop tube reactor: experiments and modelling. Fuel 2013;103:1080-9.

[26] Billaud J, Valin S, Peyrot M, Salvador S. Influence of $\mathrm{H} 2 \mathrm{O}, \mathrm{CO} 2$ and $\mathrm{O} 2$ addition on biomass gasification in entrained flow reactor conditions: Experiments and modelling. Fuel 2016;166:166-78.

[27] Chen L, Dupont C, Salvador S, Grateau M, Boissonnet G, Schweich D. Experimental study on fast pyrolysis of free-falling millimetric biomass particles between $800^{\circ} \mathrm{C}$ and $1000^{\circ} \mathrm{C}$. Fuel 2013;106:61-6.

[28] Sheng C, Azevedo JLT. Estimating the higher heating value of biomass fuels from basic analysis data. Biomass Bioenergy 2005;28:499-507.

[29] Oasmaa A, Peacocke C. A guide to physical property characterisation of biomass-derived fast pyrolysis liquids. VTT publications; 2001.

[30] Westerhof RJM, Kuipers NJM, Kersten SRA, van Swaaij WPM. Controlling the water content of biomass fast pyrolysis oil. Ind Eng Chem Res 2007;46:9238-47.

[31] B. Bunting, A. Boyd, Pyrolysis Oil Properties and Chemistry Related to Process and Upgrade Conditions for Pipeline Shipment, in, Oak Ridge National Laboratory report; 2012.

[32] Vinu R, Broadbelt LJ. A mechanistic model of fast pyrolysis of glucose-based carbohydrates to predict bio-oil composition. Energy Environ Sci 2012;5:9808-26.

[33] Nocquet T, Dupont C, Commandre J-M, Grateau M, Thiery S, Salvador S, Volatile species release during torrefaction of wood and its macromolecular constituents: Part 1 - Experimental study. Energy 2014;72:180-7.

[34] Dupont C, Boissonnet G, Seiler JM, Gauthier P, Schweich D. Study about the kinetic processes of biomass steam gasification. Fuel 2007;86:32-40. 